\title{
Magma Mingling in Kimberlites: Evidence from the Groundmass Cocrystallization of Two Spinel-Group Minerals
}

\author{
Jingyao Xu ${ }^{1,2}$, Joan Carles Melgarejo ${ }^{3}\left(\mathbb{D}\right.$, Qiuli Li ${ }^{1,2,4, *(\mathbb{C}}$, Lisard Torró i Abat ${ }^{5}$ \\ and Montgarri Castillo-Oliver ${ }^{6}$ \\ 1 State Key Laboratory of Lithospheric Evolution, Institute of Geology and Geophysics, Chinese Academy of \\ Sciences, Beijing 100029, China; jingyao.xu@hotmail.com \\ 2 Innovation Academy for Earth Science, Chinese Academy of Sciences, Beijing 100029, China \\ 3 Department of Mineralogy, Petrology and Applied Geology, Faculty of Earth Sciences, University of \\ Barcelona, 08028 Barcelona, Spain; joan.carles.melgarejo.draper@ub.edu \\ 4 College of Earth and Planetary Sciences, University of Chinese Academy of Sciences, Beijing 100049, China \\ 5 Geological Engineering Program, Faculty of Sciences and Engineering, Pontifical Catholic University of \\ Peru (PUCP), Av. Universitaria 1801, San Miguel, Lima-32, Peru; lisardtorro@hotmail.com \\ 6 ARC Centre of Excellence for Core to Crust Fluid Systems (CCFS) and GEMOC, Department of Earth and \\ Environmental Sciences, Macquarie University, North Ryde 2109, Australia; \\ montgarri.castillo-oliver@mq.edu.au \\ * Correspondence: liqiuli@mail.iggcas.ac.cn
}

Received: 15 August 2020; Accepted: 18 September 2020; Published: 20 September 2020

\begin{abstract}
We present the results of a detailed petrographic study of fresh coherent samples of the Menominee kimberlite sampled at site 73, located in Menominee County, MI, USA. Our objective is to account for its unusual and complex paragenetic sequence. Several generations of olivine, ilmenite, and spinel-group minerals are described. Early olivine and ilmenite are xenocrystic and were replaced or overgrown by primary minerals. Zoned microcrysts of olivine have a xenocrystic core mantled by a first rim in which rutile, geikielite, and spinel s.s. (spinel sensu stricto) cocrystallized. The in situ U-Pb dating of a microcryst of primary rutile yielded $168.9 \pm 4.4 \mathrm{Ma}$, which was interpreted as the age of emplacement. The groundmass consists of olivine, spinel s.s., a magnesian ulvöspinel-ulvöspinel-magnetite (MUM) spinel, calcite, and dolomite. An extremely low activity of Si is suggested by the crystallization of spinel s.s. instead of phlogopite in the groundmass. The presence of djerfisherite microcrysts indicates high activities of $\mathrm{Cl}$ and $\mathrm{S}$ during the late stages of melt crystallization. The occurrence of two distinct spinel-group minerals (spinel s.s. and qandilite-rich MUM) in the groundmass is interpreted as clear evidence of the mingling of a magnesiocarbonatitic melt with a dominant kimberlitic melt.
\end{abstract}

Keywords: magma mingling; kimberlite; rutile; U-Pb age; coexisting spinels; qandilite; djerfisherite; Menominee; Michigan; USA

\section{Introduction}

Kimberlites are mantle-derived hybrid rocks consisting of a mixture of crystals, some derived from the disaggregation of xenoliths and some that grew directly in the carrier magma [1]. These rocks clearly present a petrographic challenge due to the hybrid nature and common strong overprint by late hydrothermal and supergene processes. Such alteration processes lead to the crystallization of abundant secondary minerals and to the modification of the original bulk composition, making the study of the early magmatic processes difficult [2,3]. The study of rare fresh kimberlite samples 
is hence an appealing opportunity to understand the early evolution of these enigmatic magmas. For example, research on well-preserved kimberlites from Russia helped discover halogen-rich minerals, providing clear evidence of the high activity of volatiles [4], and the cocrystallization of two perovskite populations in Angolan kimberlites was interpreted to be generated by magma mingling [5]. Kimberlite bodies are commonly formed by multiple pulses of magma [6], which can mix during ascent or intrusion [7]. The mixture of different pulses of magma can be diagnosed by disequilibrium mineral assemblages, bimodal mineral compositions, and normal and reverse zoned minerals [7]. This is why our research team investigated the mineral associations found in kimberlites and related rocks using around 400 samples from worldwide occurrences that form part of the collection of the University of Barcelona. These samples were collected in situ during field trips to different kimberlite sites, donated by universities and mining companies worldwide, or acquired from the internet market. A selection of 60 of these samples was considered as representative and studied in detail. The purpose of the study was to compare the mineral textures and chemistry of the indicator minerals and reconstruct the paragenetic sequence. However, some intriguing textures were found in some samples and deserved special focus. Therefore, in this paper we aim to demonstrate, with examples from two selected samples from a kimberlite (site 73 in Menominee, MI, USA), that spinel groundmass associations can be a criterion to reveal the mingling processes in kimberlites.

\section{Geological Setting}

In Michigan, the Precambrian shield consists of two sutured Archean terranes, upon which Paleoproterozoic $(2.1 \mathrm{Ga})$ metasedimentary and metavolcanic rocks indicative of a passive margin and rift basin were deposited [8]. Deformation occurred at $1.9 \mathrm{Ga}$, and post-orogenic diabase dykes crosscut the Archean basement and deformed Proterozoic cover [8]. The site 73 Menominee kimberlite cuts the Ordovician sedimentary rocks laid down in a shallow sea [8]. The age of some kimberlites from this area has been established at 186-209 Ma [9]. The Lake Ellen kimberlite, which is located about $60 \mathrm{~km}$ northwest of site 73 (Figure 1), is dated at $186 \pm 6$ and $190 \pm 5 \mathrm{Ma}$ by Rb-Sr of phlogopite (unpublished data cited in [10]) and $206 \pm 9 \mathrm{Ma}$ using U-Pb systematics on rutile [11]. The site 73 Menominee kimberlite is dated to $155 \mathrm{Ma}$ from concentrated zircon macrocrysts using the fission-track method and to 190 Ma by the K-Ar of phlogopite (unpublished data cited in [8]). The Lake Ellen kimberlite is reported to have risen from a depth within the field of diamond stability [12]. It passed through a heterogeneous mantle sector that contained eclogite, garnet peridotite, garnet pyroxenite, and spinel-pyroxenite [12]. Many kimberlites found in Michigan are diamondiferous [12-16]. The presence of a diamond crystal in the site 73 Menominee kimberlites has been reported [14], although it does not seem to be economically diamondiferous $[8,16]$. 


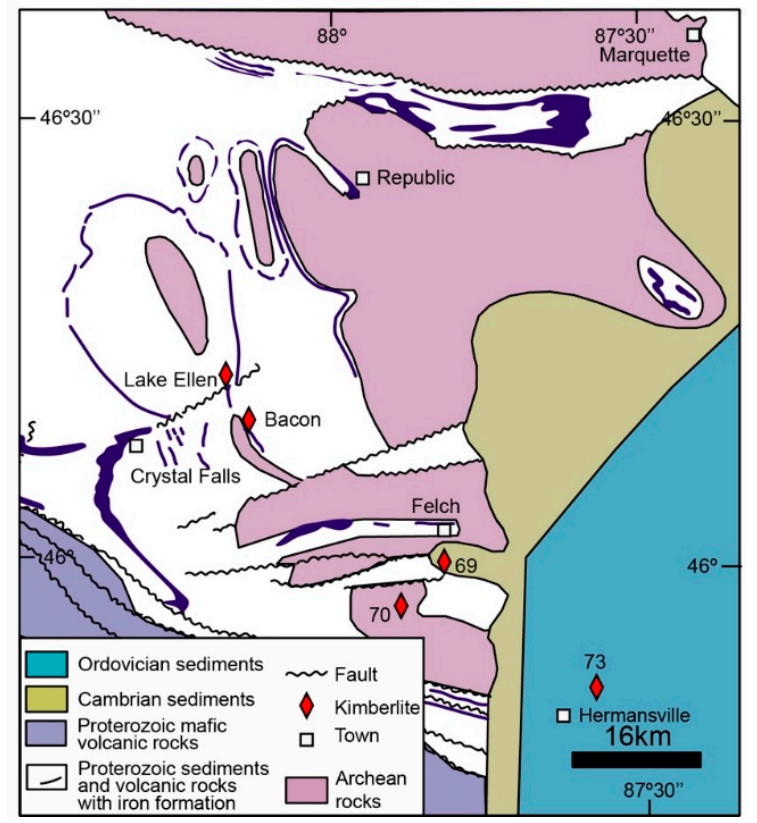

Figure 1. Geological location of the site 73 Menominee kimberlite [8].

\section{Methods}

Petrographic and textural studies were carried out using optical and scanning electron microscopy (SEM). We used an E-SEM-Quanta 200 FEI-XTE-325/D8395 with a Back-Scattered Electron (BSE) detector, coupled to a Genesis energy-dispersive spectrometer (EDS) microanalysis system, at the Scientific and Technical Centers of the University of Barcelona (CCiTUB). The operating conditions were $20 \mathrm{kV}, 1 \mathrm{nA}$ beam current, $1 \mu \mathrm{m}$ beam diameter, and $10 \mathrm{~mm}$ distance to detector. We determined the chemical composition of the spinel-group minerals, ilmenite-group minerals, rutile, and olivine using an electron microprobe (EMP) JEOL JXA-8230 (JEOL, Tokyo, Japan) equipped with five wavelength-dispersive spectrometers (WDS) and one energy-dispersive spectrometer (EDS), also at the CCiTUB. The detection limits for olivine were as follows: $107 \mathrm{ppm}$ for $\mathrm{Si}, 184 \mathrm{ppm}$ for $\mathrm{Mg}, 127 \mathrm{ppm}$ for $\mathrm{Mn}, 118 \mathrm{ppm}$ for $\mathrm{Fe}, 118 \mathrm{ppm}$ for $\mathrm{Ni}$ and $58 \mathrm{ppm}$ for $\mathrm{Ca}$. In situ $\mathrm{U}-\mathrm{Pb}$ analyses of primary rutile were carried out by secondary ion mass spectrometry (SIMS) using a CAMECA IMS 1280HR ion microprobe at the Institute of Geology and Geophysics, Chinese Academy of Sciences (IGGCAS). Details of the SIMS analytical method are described in [17-19]. The $\mathrm{O}^{-}$primary ion beam was accelerated at $-13 \mathrm{kV}$, with an intensity of ca. $30 \mathrm{nA}$. The spot was approximately $20 \mu \mathrm{m} \times 30 \mu \mathrm{m}$ and oval in shape. Each measurement consisted of 10 cycles and took approximately $15 \mathrm{~min}$. The $\mathrm{Pb} / \mathrm{U}$ ratios were calibrated using a DXK rutile standard (1782.6 $\pm 2.8 \mathrm{Ma})[20]$.

\section{Textural Descriptions}

Our specimens are hypabyssal kimberlites; they are uniform, xenolith-poor, fine- to medium-grained, olivine-rich, and coherent. They consist of macrocrysts $(>1 \mathrm{~mm})$ of ilmenite $(<3$ modal $\%$ ), olivine ( $4-5$ modal $\%$ ), and phlogopite (1-2 modal $\%)$; microphenocrysts $(<1 \mathrm{~mm}$ ) of olivine ( $<40$ modal $\%)$; and a groundmass made up of olivine microphenocrysts (10-15 modal\%), carbonates (10-12 modal\% calcite and 10-12 modal\% dolomite), and spinel-group minerals (10 modal\% magnesian ulvöspinel-ulvöspinel-magnetite (MUM) and 8 modal\% spinel sensu stricto (s.s.)). Microcrysts of djerfisherite $\left(\mathrm{K}_{6}(\mathrm{Fe}, \mathrm{Cu}, \mathrm{Ni}){ }_{25} \mathrm{~S}_{26} \mathrm{Cl}\right)$ and rutile were also observed $(<1$ modal $\%)$.

The olivine is relatively fresh. The anhedral macrocrystic olivine ranges from $2 \mathrm{~cm}$ down to $1 \mathrm{~mm}$ across. Euhedral microphenocrysts of olivine $(0.2-0.5 \mathrm{~mm})$ are fresh and display complex zoning (labeled as $\mathrm{Ol} 1$ to $\mathrm{Ol} 3$ from the core to the outermost rim, Figure 2a). The core of the olivine crystals (Ol1) has inclusions of pentlandite and pyrrhotite; these sulfides have a roundish shape and are 
fine-grained. A first rim of euhedral olivine (O12) mantles the core and contains inclusions of subhedral rutile crystals, which are set mostly at the contact between the core and this rim. The outermost rim of euhedral olivine (Ol3) contains inclusions of spinel sensu stricto (Al-Mg spinel) and $\mathrm{Mg}$-rich ilmenite (Figure $2 b$ ). The groundmass olivine ranges from 10 to $50 \mu \mathrm{m}$ across; it is partially replaced by a serpentine.

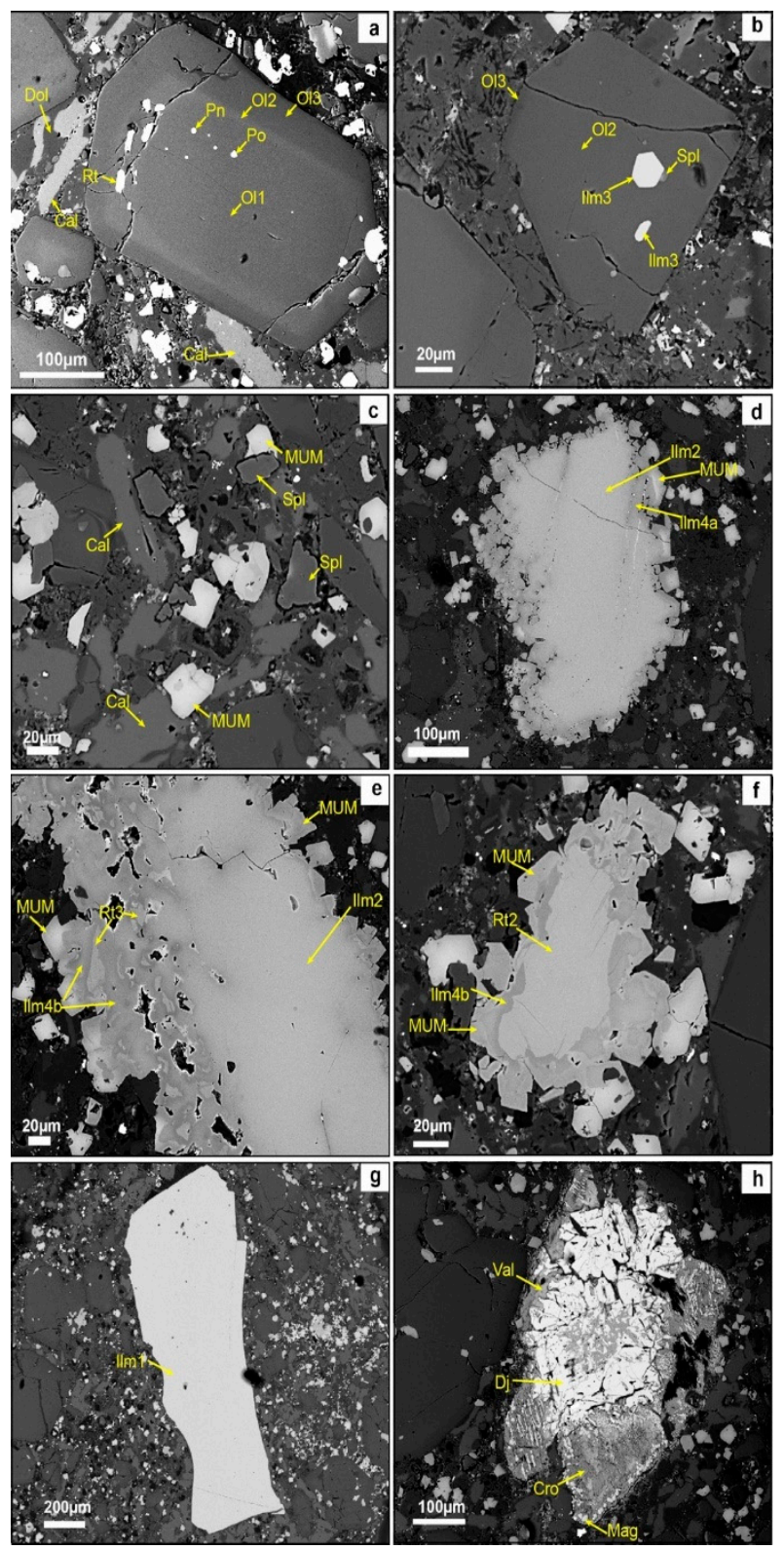

Figure 2. (a) A zoned euhedral olivine phenocryst. Olivine 1 (Ol1) is anhedral and contains inclusions of pentlandite (Pn) and pyrrhotite (Po); the ensemble has a first rim of olivine $2(\mathrm{Ol} 2)$ containing rutile (Rt1) and an outermost rim of olivine 3 (Ol3); (b) ilmenite (Ilm3) and spinel (Spl) found as inclusions in olivine 2 (Ol2); (c) spinel s.s. (Spl), ulvöspinel-ulvöspinel-magnetite (MUM), calcite (Cal), and dolomite (Dol) coexist in the groundmass; (d) ilmenite (Ilm2) replaced first by ilmenite 4a (Ilm4a) and finally by MUM; (e) ilmenite (Ilm2) replaced by rutile (Rt3), and lastly replaced by geiliete (Ilm 4b) and MUM; (f) microcrystic rutile (Rt2) replaced by ilmenite (Ilm 4b) and MUM; (g) homogeneous ilmenite (Ilm1) not replaced by other minerals; (h) djerfisherite (Dj) replaced by valleriite (Val), magnetite (Mag), and cronstedtite (Cro). 
Two different spinel-group minerals have been identified in the groundmass; one is spinel sensu stricto, and the other is labeled MUM. These two spinels occur in similar proportions in the groundmass, and there is no overgrowth of one on the other. The Al-Mg-rich spinel (82-90 mol.\% $\left.\mathrm{MgAl}_{2} \mathrm{O}_{4}\right)$ is commonly euhedral to subhedral in the groundmass, but it is also found as small inclusions in fresh olivine, together with geikielite (Figure 2c). The groundmass spinel s.s. is found locally replaced by fine-grained aggregates of meixnerite $\left(\mathrm{Mg}_{6} \mathrm{Al}_{2}(\mathrm{OH})_{16}(\mathrm{OH})_{2} \cdot 4 \mathrm{H}_{2} \mathrm{O}\right)$ at the rim. The second spinel-group mineral found in the groundmass is MUM, and it shows an euhedral outline (Figure 2c); it is also found as the last phase replacing Mg-rich ilmenite and rutile macrocrysts (Figure $2 \mathrm{~d}-\mathrm{f}$ ).

Four textural types of ilmenite-group minerals are present: (1) homogeneous macro- to microcrystic Mg-rich ilmenite (Figure 2g); (2) macro- to microcrystic Mg-rich ilmenite replaced along veinlets and grain borders by a sequence of rutile, geikielite, and qandilite (Figure 2d,e); (3) euhedral to anhedral geikielite as inclusions in the olivine rim Ol3 (Figure 2b); (4) geikielite replacing type-2 Mg-rich ilmenite (type 4a, Figure 2d), rutile microphenocrysts (type 4b, Figure 2f), and rutile included in olivine (type 4c).

Rutile shows three different textural types: (1) euhedral rutile, as very common inclusions in olivine, at the contact between the olivine core (Ol1) and the first rim (Ol2) (Figure 2a); (2) rutile microphenocrysts (about $200 \mu \mathrm{m}$ ), which are replaced by geikielite along their margins and along fractures, and then by qandilite (Figure 2f); (3) rutile replacing macro- to microcrysts of $\mathrm{Mg}$-rich ilmenite (Figure 2e) and which, in turn, is replaced by geikielite and MUM.

Djerfisherite microcrysts are found as anhedral grains of up to $400 \mu \mathrm{m}$ (Figure $2 \mathrm{~h}$ ). They are partly replaced by a sequence of valleriite $\left.\left(\mathrm{Fe}^{2+}, \mathrm{Cu}\right)_{4}(\mathrm{Mg}, \mathrm{Al})_{3} \mathrm{~S}_{4}(\mathrm{OH}, \mathrm{O})_{6}\right)$ and galena, followed by magnetite and cronstedtite $\left(\left(\mathrm{Fe}^{2+}, \mathrm{Fe}^{3+}\right)_{3}\left(\mathrm{Si}, \mathrm{Fe}^{3+}\right)_{2} \mathrm{O}_{5}(\mathrm{OH})_{4}\right)$.

Subhedral laths of calcite (about 50 to $100 \mu \mathrm{m}$ in length) occur in the kimberlite groundmass. Anhedral dolomite in the groundmass fills the interstitial spaces between the above-mentioned minerals (Figure 2c). MUM is found commonly in contact with dolomite. Barite forms small anhedral crystals $(<1$ to $5 \mu \mathrm{m})$ associated with dolomite and also in association with secondary minerals such as meixnerite and serpentine.

\section{Mineral Chemistry}

Cores of olivine microphenocrysts (Ol1) contain 90.8-91.1 mol.\% Fo component, with the highest $\mathrm{Ni}(0.37-0.41$ wt.\% NiO) and $\mathrm{Ca}(0.10-0.13$ wt.\% $\mathrm{CaO})$ contents (Figure 3$)$. The first rim (Ol2) has slightly lower Mg (90.4-90.9 mol.\% Fo, Fo90.6 on average), Ni (0.17-0.24 wt.\% NiO), and Ca (0.04-0.05 wt.\% CaO) contents than the core (Figure 3). The outer rim has a higher Mg content (91.4-94.5 mol.\% Fo, Fo92.7 on average) and a slightly lower Ni content than the inner rim (Figure 3). The Mn contents are similar in the three zones (Figure 3).
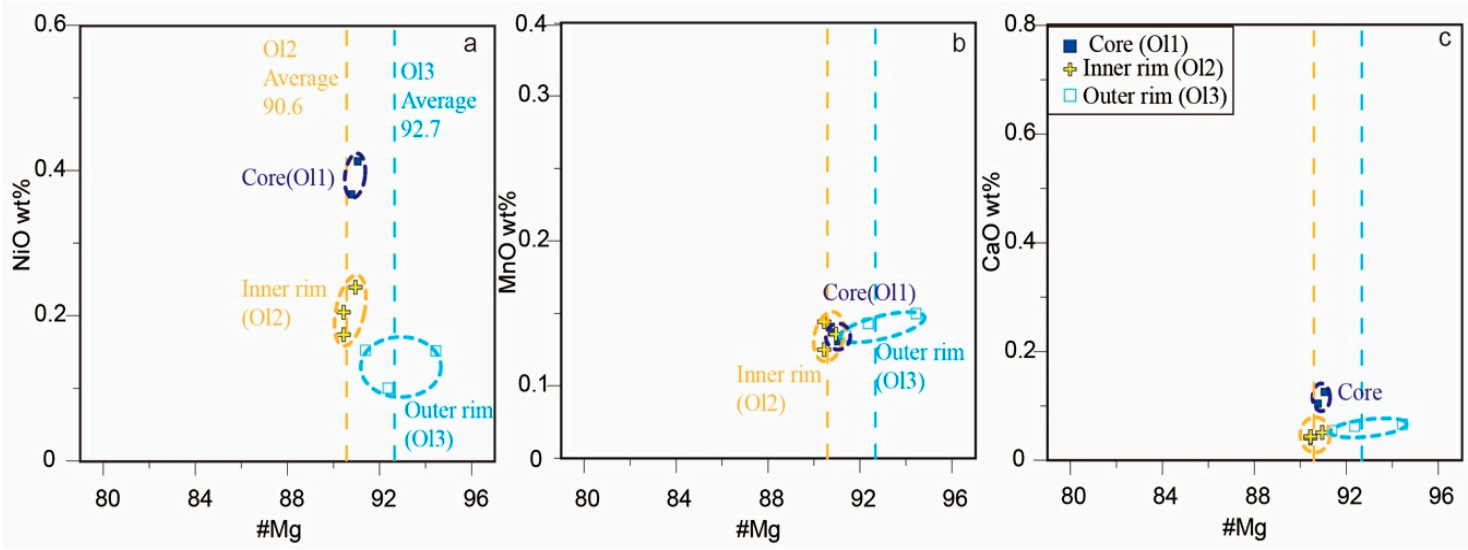

Figure 3. Compositional relations of (a) \#Mg vs. $\mathrm{NiO},(\mathbf{b}) \# \mathrm{Mg}$ vs. $\mathrm{MnO}$, and (c) \#Mg vs. CaO of olivine at the Menominee kimberlite. 
Two spinel-group minerals occur in the groundmass (Figure 4, Table 1), with compositions typical of Al-Mg spinel (spinel s.s.) and MUM (magnesian ulvöspinel-ulvöspinel-magnetite). The first one contains 82-90 mol. $\% \mathrm{MgAl}_{2} \mathrm{O}_{4}, 3-10$ mol. $\% \mathrm{FeCr}_{2} \mathrm{O}_{4}, 5-6$ mol. $\% \mathrm{Fe}_{3} \mathrm{O}_{4}$, and 1-3 mol. $\% \mathrm{Mg}_{2} \mathrm{TiO}_{4}$. The spinel s.s. included in olivine phenocrysts has a similar composition to that found in the groundmass. The second spinel in the groundmass, the euhedral grains of MUM, has significant contents of the qandilite component (28-56 mol.\% $\mathrm{Mg}_{2} \mathrm{TiO}_{4}$ ), as well as $22-46 \mathrm{~mol} . \% \mathrm{Fe}_{3} \mathrm{O}_{4}, 5-19$ mol.\% $\mathrm{MgAl}_{2} \mathrm{O}_{4}$, and 3-15 mol.\% $\mathrm{Fe}_{2} \mathrm{TiO}_{4}$. Where this spinel occurs as a replacement product of geikielite xenocrysts, it is even more enriched in $\mathrm{Mg}$ and approaches the qandilite end-member (Mg up to $1.26 \mathrm{apfu}$, following the trend G indicated in Figure 4). In the case of the euhedral MUM in the groundmass, it increases in $\mathrm{Mg}$ content toward its rim, but the most external Mg-rich MUM rim is too thin to analyze.

Table 1. Representative electron microprobe (EMP) analyses of spinel-group minerals.

\begin{tabular}{|c|c|c|c|c|c|c|c|c|}
\hline Type & \multicolumn{4}{|c|}{ MUM-g MUM-g MUM-r MUM-r } & Sp-o & Sp-o & Sp-g & Sp-g \\
\hline \multicolumn{9}{|l|}{ wt.\% } \\
\hline $\mathrm{SiO}_{2}$ & bdl & bdl & 0.06 & 0.02 & bdl & 0.12 & bdl & 0.11 \\
\hline $\mathrm{Al}_{2} \mathrm{O}_{3}$ & 2.62 & 9.94 & 7.86 & 7.54 & 52.33 & 58.92 & 59.05 & 57.00 \\
\hline $\mathrm{MgO}$ & 14.39 & 18.19 & 28.11 & 26.26 & 21.09 & 22.31 & 21.99 & 21.58 \\
\hline $\mathrm{ZnO}$ & 0.06 & bdl & bdl & bdl & bdl & 0.05 & 0.04 & 0.07 \\
\hline $\mathrm{FeO}$ & 25.58 & 20.13 & 13.71 & 17.53 & 8.73 & 6.90 & 7.35 & 8.34 \\
\hline $\mathrm{Fe}_{2} \mathrm{O}_{3}$ & 36.00 & 32.36 & 20.42 & 17.21 & 6.00 & 5.54 & 5.31 & 5.22 \\
\hline $\mathrm{MnO}$ & 0.33 & 0.40 & 0.49 & 0.52 & 0.09 & 0.10 & 0.11 & 0.07 \\
\hline $\mathrm{V}_{2} \mathrm{O}_{3}$ & 0.57 & 0.60 & 0.28 & 0.30 & 0.22 & 0.17 & 0.17 & 0.20 \\
\hline $\mathrm{Cr}_{2} \mathrm{O}_{3}$ & 1.15 & 0.43 & 1.32 & 1.87 & 9.28 & 3.33 & 3.52 & 4.59 \\
\hline $\mathrm{TiO}_{2}$ & 18.36 & 17.34 & 26.99 & 28.14 & 1.19 & 0.66 & 0.80 & 1.20 \\
\hline $\mathrm{Nb}_{2} \mathrm{O}_{5}$ & 0.07 & 0.02 & 0.11 & 0.05 & 0.05 & bdl & bdl & bdl \\
\hline $\mathrm{ZrO}_{2}$ & bdl & bdl & 0.17 & 0.20 & bdl & bdl & bdl & bdl \\
\hline $\mathrm{NiO}$ & 0.28 & 0.16 & 0.09 & 0.12 & 0.16 & 0.17 & 0.16 & 0.16 \\
\hline $\mathrm{CaO}$ & 0.16 & 0.19 & 0.14 & 0.08 & 0.08 & 0.16 & 0.46 & 0.16 \\
\hline Total & 99.58 & 99.79 & 99.73 & 99.87 & 99.39 & 98.43 & 99.06 & 98.75 \\
\hline apfu & \multicolumn{8}{|c|}{ Cations on the basis of $4 \mathrm{O}$ atoms } \\
\hline $\mathrm{Si}$ & 0.00 & 0.00 & 0.00 & 0.00 & 0.00 & 0.00 & 0.00 & 0.00 \\
\hline $\mathrm{Al}$ & 0.10 & 0.37 & 0.28 & 0.27 & 1.63 & 1.79 & 1.79 & 1.75 \\
\hline $\mathrm{Mg}$ & 0.72 & 0.86 & 1.25 & 1.18 & 0.83 & 0.86 & 0.84 & 0.84 \\
\hline $\mathrm{Zn}$ & 0.00 & 0.00 & 0.00 & 0.00 & 0.00 & 0.00 & 0.00 & 0.00 \\
\hline $\mathrm{Fe}^{2+}$ & 0.72 & 0.53 & 0.34 & 0.44 & 0.19 & 0.15 & 0.16 & 0.18 \\
\hline $\mathrm{Fe}^{3+}$ & 0.91 & 0.77 & 0.46 & 0.39 & 0.12 & 0.11 & 0.10 & 0.10 \\
\hline $\mathrm{Mn}$ & 0.01 & 0.01 & 0.01 & 0.01 & 0.00 & 0.00 & 0.00 & 0.00 \\
\hline $\mathrm{V}$ & 0.02 & 0.02 & 0.01 & 0.01 & 0.00 & 0.00 & 0.00 & 0.00 \\
\hline $\mathrm{Cr}$ & 0.03 & 0.01 & 0.03 & 0.04 & 0.19 & 0.07 & 0.07 & 0.09 \\
\hline $\mathrm{Ti}$ & 0.47 & 0.41 & 0.61 & 0.64 & 0.02 & 0.01 & 0.02 & 0.02 \\
\hline $\mathrm{Nb}$ & 0.00 & 0.00 & 0.00 & 0.00 & 0.00 & 0.00 & 0.00 & 0.00 \\
\hline $\mathrm{Zr}$ & 0.00 & 0.00 & 0.00 & 0.00 & 0.00 & 0.00 & 0.00 & 0.00 \\
\hline $\mathrm{Ni}$ & 0.01 & 0.00 & 0.00 & 0.00 & 0.00 & 0.00 & 0.00 & 0.00 \\
\hline $\mathrm{Ca}$ & 0.01 & 0.01 & 0.00 & 0.00 & 0.00 & 0.00 & 0.01 & 0.00 \\
\hline $\mathrm{MgAl}_{2} \mathrm{O}_{4}$ & 5.26 & 18.75 & 13.98 & 13.54 & 81.90 & 89.51 & 89.15 & 87.30 \\
\hline $\mathrm{Fe}_{3} \mathrm{O}_{4}$ & 46.15 & 38.97 & 23.19 & 19.73 & 5.99 & 5.61 & 5.44 & 5.33 \\
\hline $\mathrm{Mg}_{2} \mathrm{TiO}_{4}$ & 33.41 & 33.79 & 55.06 & 51.64 & 2.37 & 1.34 & 1.63 & 2.45 \\
\hline $\mathrm{Mn}_{2} \mathrm{TiO}_{4}$ & 0.47 & 0.54 & 0.61 & 0.66 & 0.00 & 0.00 & 0.00 & 0.00 \\
\hline $\mathrm{Fe}_{2} \mathrm{TiO}_{4}$ & 13.17 & 7.40 & 5.58 & 12.18 & 0.00 & 0.00 & 0.00 & 0.00 \\
\hline $\mathrm{FeCr}_{2} \mathrm{O}_{4}$ & 1.55 & 0.55 & 1.58 & 2.25 & 9.74 & 3.54 & 3.78 & 4.92 \\
\hline $\mathrm{MnCr}_{2} \mathrm{O}_{4}$ & 0.00 & 0.00 & 0.00 & 0.00 & 0.00 & 0.00 & 0.00 & 0.00 \\
\hline $\mathrm{MgCr}_{2} \mathrm{O}_{4}$ & 0 & 0 & 0 & 0 & 0 & 0.00 & 0.00 & 0.00 \\
\hline
\end{tabular}

bdl: below detection limit; MUM-g: groundmass MUM; MUM-r: MUM replacing ilmenite; sp-o: spinel s.s. inclusion in olivine; sp-g: spinel s.s. in groundmass. 


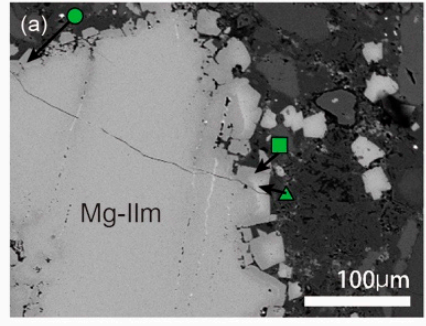

(d)
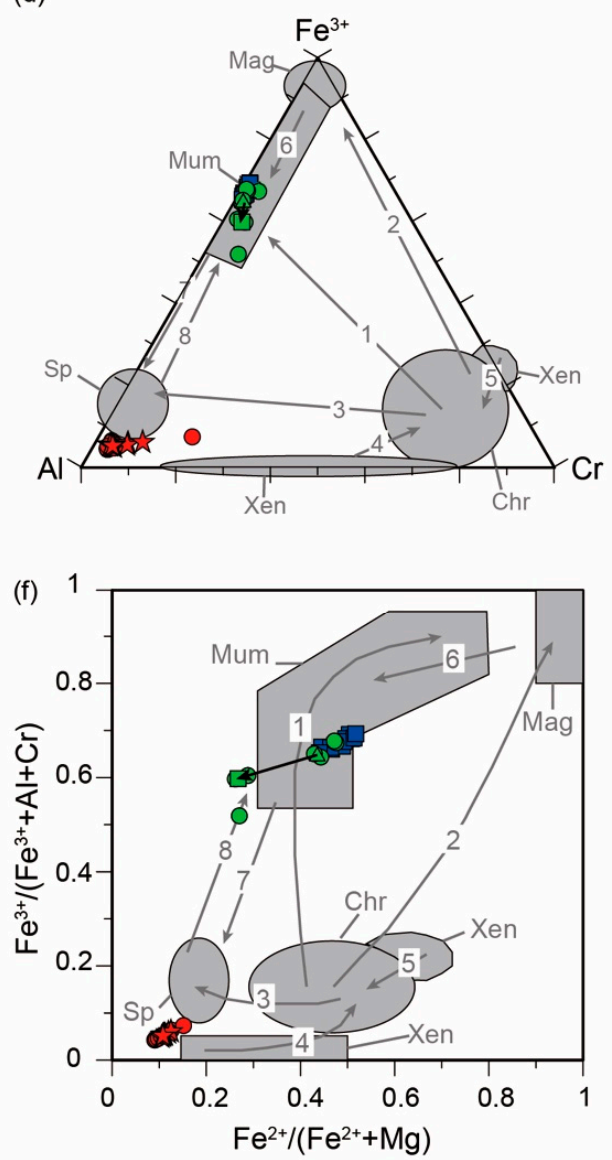

(h)

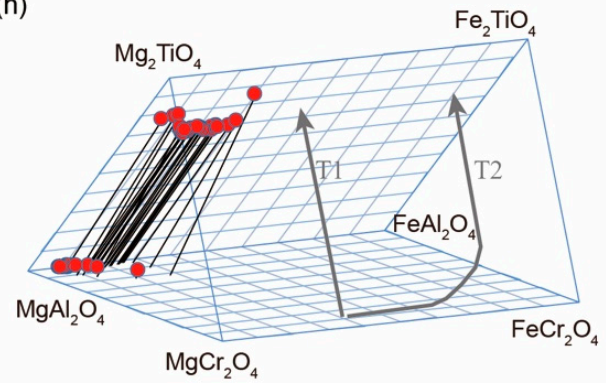

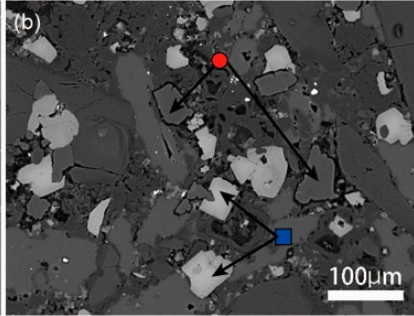

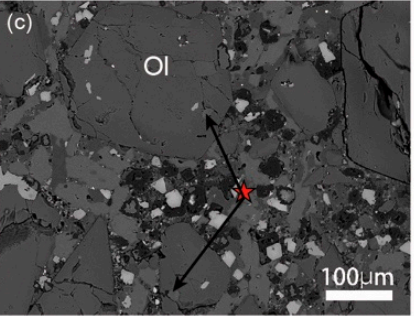

(e)
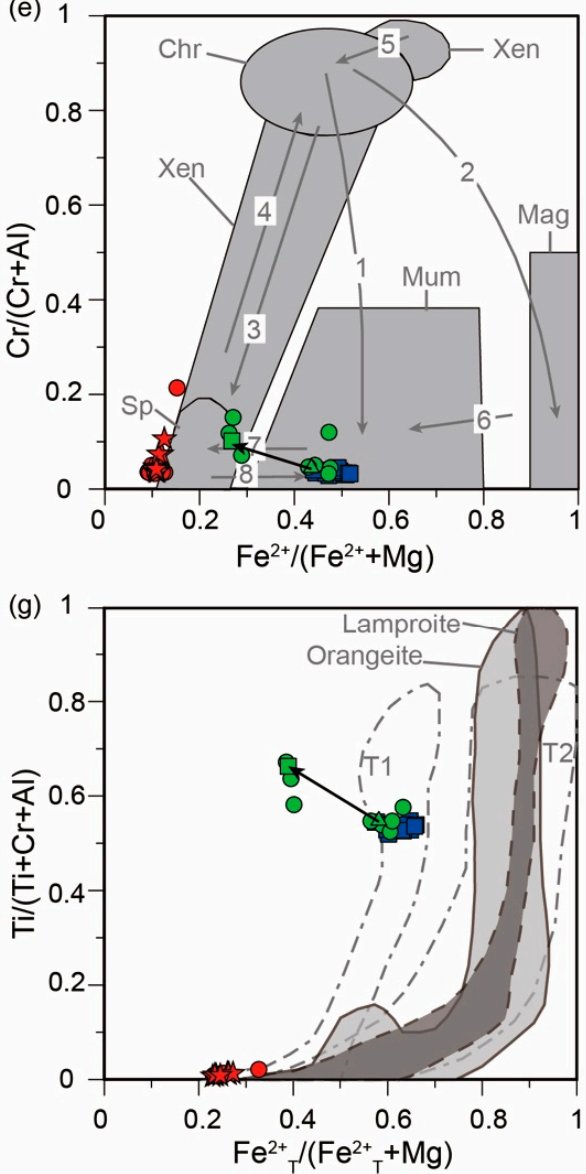

(i)

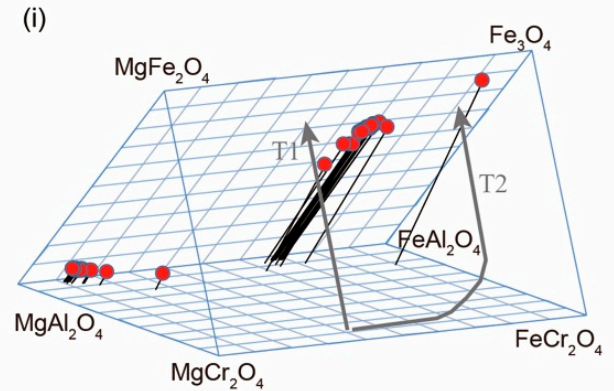

Figure 4. (a-c) Groundmass spinel with the situation of some analyzed points in Back-Scattered Electron (BSE) imaging. Compositions of primary spinels from Menominee in the following diagrams: (d) $\mathrm{Al}-\mathrm{Cr}-\mathrm{Fe}^{3+}$, (e) $\mathrm{Fe}^{2+} /\left(\mathrm{Fe}^{2+}+\mathrm{Mg}\right)$ vs. $\mathrm{Cr} /(\mathrm{Cr}+\mathrm{Al})$, (f) $\mathrm{Fe}^{2+} /\left(\mathrm{Fe}^{2+}+\mathrm{Mg}\right) \mathrm{vs} . \mathrm{Fe}^{3+} /\left(\mathrm{Fe}^{3+}+\mathrm{Cr}+\mathrm{Al}\right)$, and $(\mathrm{g}) \mathrm{Fe}^{2+} \mathrm{T} /\left(\mathrm{Fe}^{2+} \mathrm{T}+\mathrm{Mg}\right)$ vs. $\mathrm{Ti} /(\mathrm{Ti}+\mathrm{Cr}+\mathrm{Al})$. Red symbols in $(\mathbf{d}-\mathbf{g})$ correspond to the points in $(\mathbf{a}-\mathbf{c})$, and green circles are the rest of the primary spinels analyzed in this kimberlite; compositions of the spinels are also plotted in the reduced (h) and oxidized (i) spinel prisms. Compositional fields and trends from previous works are shaded in grey. (d-f) Sp: spinel s.s.; Xen: xenolith; and Chr: chromite, from [21]. (g-i) T1 and T2: trend 1 and trend 2, from [1,22]. 
Of the four texturally distinct ilmenite-group minerals present, types 1 and 2 have similar compositions and are mostly Mg-rich ilmenite, with the lowest content of $\mathrm{Mg}(12.4-14.6 \mathrm{wt} . \% \mathrm{MgO}$, 0.43-0.47 apfu Mg) and a low $\mathrm{Cr}$ content (0.7-1.4 wt.\% $\mathrm{Cr}_{2} \mathrm{O}_{3}$ ) (Figure 5). Types 3 and 4 a have similar compositions and are classified as geikielite, being enriched in $\mathrm{Mg}$ relative to types 1 and 2 (Figure 5a). Type 3 ilmenite-group minerals have 0.53-0.55 apfu $\mathrm{Mg}$ (16.0-16.4 wt.\% MgO) and 1.9-3.0 wt.\% $\mathrm{Cr}_{2} \mathrm{O}_{3}$. Type 4a, replacing macro- to microcrystal ilmenite, has 0.55-0.60 apfu Mg (16.3-18.3 wt.\% MgO), which is similar to type 3, and 0.8-1.2 wt.\% $\mathrm{Cr}_{2} \mathrm{O}_{3}$, which is lower than in type 3 (Figure $5 \mathrm{~b}$ ). Types $4 \mathrm{~b}$ and $4 \mathrm{c}$, replacing rutile, are characterized by a higher $\mathrm{Mg}(20.2-26.0$ wt.\% $\mathrm{MgO}, 0.66-0.81 \mathrm{apfu} \mathrm{Mg})$ than all the other types, as well as a higher $\mathrm{Cr}$ content (1.6-5.7 wt.\% $\mathrm{Cr}_{2} \mathrm{O}_{3}$ ) (Figure $5 \mathrm{~d}$ ). All the compositions of the ilmenite-group minerals are plotted in the kimberlite field, which was established by [23]. They show a positive correlation between $\mathrm{TiO}_{2}$ and $\mathrm{MgO}$ contents (Figure 5c). The negative correlation between $\mathrm{Mg}$ and $\mathrm{Fe}^{2+}$ points to the substitution of $\mathrm{Fe}^{2+}$ by $\mathrm{Mg}$ from types 1 and 2 to types 3 and $4 \mathrm{a}$ and, finally, to types $4 \mathrm{~b}$ and $4 \mathrm{c}$ (Figure 5e). All the textural types of ilmenite-group minerals have low levels of $\mathrm{Mn}, \mathrm{Nb}$, and $\mathrm{Zr}(<0.3 \mathrm{wt} . \%)$; types $4 \mathrm{~b}$ and $4 \mathrm{c}$ are slightly enriched in Mn (Figure 5f). Representative compositions of ilmenite-group minerals are listed in Table 2.

Table 2. Representative analyses of different types and subtypes of ilmenite and rutile.

\begin{tabular}{|c|c|c|c|c|c|c|c|c|c|c|c|c|}
\hline \multirow{2}{*}{$\begin{array}{c}\text { Mineral } \\
\text { Type }\end{array}$} & \multicolumn{6}{|c|}{ Ilmenite } & \multicolumn{6}{|c|}{ Rutile } \\
\hline & 1 & 2 & 3 & $4 a$ & $4 b$ & $4 c$ & 1 & 1 & 2 & 2 & 3 & 3 \\
\hline \multicolumn{13}{|l|}{ wt.\% } \\
\hline $\mathrm{SiO}_{2}$ & bdl & bdl & 0.05 & bdl & bdl & 0.10 & 0.05 & 0.08 & bdl & bdl & bdl & 0.03 \\
\hline $\mathrm{Al}_{2} \mathrm{O}_{3}$ & 0.39 & 0.29 & 0.53 & 0.35 & 0.04 & 0.03 & bdl & bdl & bdl & bdl & bdl & bdl \\
\hline $\mathrm{MgO}$ & 13.96 & 12.88 & 16.08 & 17.49 & 26.00 & 23.65 & 0.62 & 0.15 & bdl & 0.11 & 0.12 & bdl \\
\hline $\mathrm{ZnO}$ & bdl & bdl & bdl & bdl & bdl & bdl & 0.73 & 0.84 & 0.21 & 0.17 & 0.40 & 0.30 \\
\hline $\mathrm{FeO}$ & 23.71 & 25.18 & 20.26 & 19.15 & 7.39 & 11.30 & bdl & bdl & bdl & bdl & bdl & bdl \\
\hline $\mathrm{Fe}_{2} \mathrm{O}_{3}$ & 4.82 & 5.35 & 4.51 & 4.27 & bdl & bdl & - & - & - & - & - & - \\
\hline $\mathrm{MnO}$ & 0.32 & 0.29 & 0.27 & 0.33 & 0.56 & 0.44 & bdl & bdl & bdl & bdl & bdl & bdl \\
\hline $\mathrm{V}_{2} \mathrm{O}_{3}$ & 0.60 & 0.68 & 0.55 & 0.62 & 0.58 & 0.57 & 0.75 & 0.86 & 0.68 & 0.78 & 0.59 & 0.68 \\
\hline $\mathrm{Cr}_{2} \mathrm{O}_{3}$ & 1.18 & 0.76 & 2.41 & 1.16 & 3.28 & 1.61 & 1.55 & 4.45 & 1.18 & 2.98 & 0.84 & 1.16 \\
\hline $\mathrm{TiO}_{2}$ & 54.61 & 53.74 & 54.87 & 56.32 & 61.60 & 62.36 & 94.83 & 91.46 & 96.60 & 94.45 & 97.49 & 96.60 \\
\hline $\mathrm{Nb}_{2} \mathrm{O}_{5}$ & 0.07 & 0.23 & 0.09 & 0.11 & 0.17 & 0.30 & 1.31 & 1.62 & 1.05 & 1.72 & 0.90 & 1.16 \\
\hline $\mathrm{ZrO}_{2}$ & 0.07 & bdl & 0.10 & bdl & 0.06 & 0.06 & 0.14 & 0.24 & 0.30 & 0.31 & 0.22 & 0.27 \\
\hline $\mathrm{NiO}$ & 0.17 & 0.13 & 0.13 & 0.10 & 0.05 & 0.09 & 0.03 & 0.03 & 0.02 & bdl & bdl & bdl \\
\hline $\mathrm{CaO}$ & 0.13 & 0.03 & 0.19 & 0.03 & 0.12 & 0.01 & 0.05 & 0.01 & 0.07 & 0.05 & 0.27 & 0.09 \\
\hline Total & 100.06 & 99.63 & 100.04 & 100.00 & 99.86 & 100.51 & 100.10 & 099.77 & 100.16 & 100.62 & 100.86 & 100.35 \\
\hline apfu & \multicolumn{6}{|c|}{ Cations on the basis of $3 \mathrm{O}$ atoms } & \multicolumn{6}{|c|}{ Cations on the basis of $2 \mathrm{O}$ atoms } \\
\hline $\mathrm{Si}$ & 0.00 & 0.00 & 0.00 & 0.00 & 0.00 & 0.00 & 0.00 & 0.00 & 0.00 & 0.00 & 0.00 & 0.00 \\
\hline $\mathrm{Al}$ & 0.01 & 0.01 & 0.01 & 0.01 & 0.00 & 0.00 & 0.00 & 0.00 & 0.00 & 0.00 & 0.00 & 0.00 \\
\hline $\mathrm{Mg}$ & 0.47 & 0.44 & 0.54 & 0.58 & 0.81 & 0.75 & 0.01 & 0.00 & 0.00 & 0.00 & 0.00 & 0.00 \\
\hline $\mathrm{Zn}$ & 0.00 & 0.00 & 0.00 & 0.00 & 0.00 & 0.00 & 0.00 & 0.00 & 0.00 & 0.00 & 0.00 & 0.00 \\
\hline $\mathrm{Fe}^{2+}$ & 0.45 & 0.49 & 0.38 & 0.36 & 0.13 & 0.20 & 0.01 & 0.01 & 0.00 & 0.00 & 0.00 & 0.00 \\
\hline $\mathrm{Fe}^{3+}$ & 0.08 & 0.09 & 0.08 & 0.07 & 0.00 & 0.00 & - & - & - & - & - & - \\
\hline $\mathrm{Mn}$ & 0.01 & 0.01 & 0.01 & 0.01 & 0.01 & 0.01 & 0.00 & 0.00 & 0.00 & 0.00 & 0.00 & 0.00 \\
\hline $\mathrm{V}$ & 0.01 & 0.01 & 0.01 & 0.01 & 0.01 & 0.01 & 0.01 & 0.01 & 0.01 & 0.01 & 0.01 & 0.01 \\
\hline $\mathrm{Cr}$ & 0.02 & 0.01 & 0.04 & 0.02 & 0.05 & 0.03 & 0.02 & 0.05 & 0.01 & 0.03 & 0.01 & 0.01 \\
\hline $\mathrm{Ti}$ & 0.94 & 0.93 & 0.93 & 0.94 & 0.97 & 1.00 & 0.96 & 0.94 & 0.97 & 0.95 & 0.97 & 0.97 \\
\hline $\mathrm{Nb}$ & 0.00 & 0.00 & 0.00 & 0.00 & 0.00 & 0.00 & 0.01 & 0.01 & 0.01 & 0.01 & 0.01 & 0.01 \\
\hline $\mathrm{Zr}$ & 0.00 & 0.00 & 0.00 & 0.00 & 0.00 & 0.00 & 0.00 & 0.00 & 0.00 & 0.00 & 0.00 & 0.00 \\
\hline $\mathrm{Ni}$ & 0.00 & 0.00 & 0.00 & 0.00 & 0.00 & 0.00 & 0.00 & 0.00 & 0.00 & 0.00 & 0.00 & 0.00 \\
\hline $\mathrm{Ca}$ & 0.00 & 0.00 & 0.00 & 0.00 & 0.00 & 0.00 & 0.00 & 0.00 & 0.00 & 0.00 & 0.00 & 0.00 \\
\hline Total & 2.00 & 2.00 & 2.00 & 2.00 & 2.00 & 2.00 & 1.02 & 1.02 & 1.01 & 1.01 & 1.01 & 1.01 \\
\hline $\mathrm{Fe}^{2+} /\left(\mathrm{Mg}+\mathrm{Fe}^{2+}\right)$ & 0.15 & 0.17 & 0.12 & 0.11 & 0.00 & 0.00 & - & - & - & - & - & - \\
\hline $\mathrm{Mn} /\left(\mathrm{Mn}+\mathrm{Fe}^{2+}+\mathrm{Mg}\right)$ & 0.01 & 0.01 & 0.01 & 0.01 & 0.01 & 0.01 & - & - & - & - & - & - \\
\hline $\mathrm{FeTiO}_{3}$ & 46.42 & 49.54 & 39.55 & 36.42 & 13.61 & 20.97 & - & - & - & - & - & - \\
\hline $\mathrm{Fe}_{2} \mathrm{O}_{3}$ & 4.24 & 4.74 & 3.97 & 3.66 & 0.00 & 0.00 & - & - & - & - & - & - \\
\hline $\mathrm{MnTiO}_{3}$ & 0.64 & 0.58 & 0.54 & 0.63 & 1.05 & 0.82 & - & - & - & - & - & - \\
\hline $\mathrm{MgTiO}_{3}$ & 48.69 & 45.15 & 55.95 & 59.29 & 85.34 & 78.21 & - & - & - & - & - & - \\
\hline
\end{tabular}

bdl: below detection limit. 


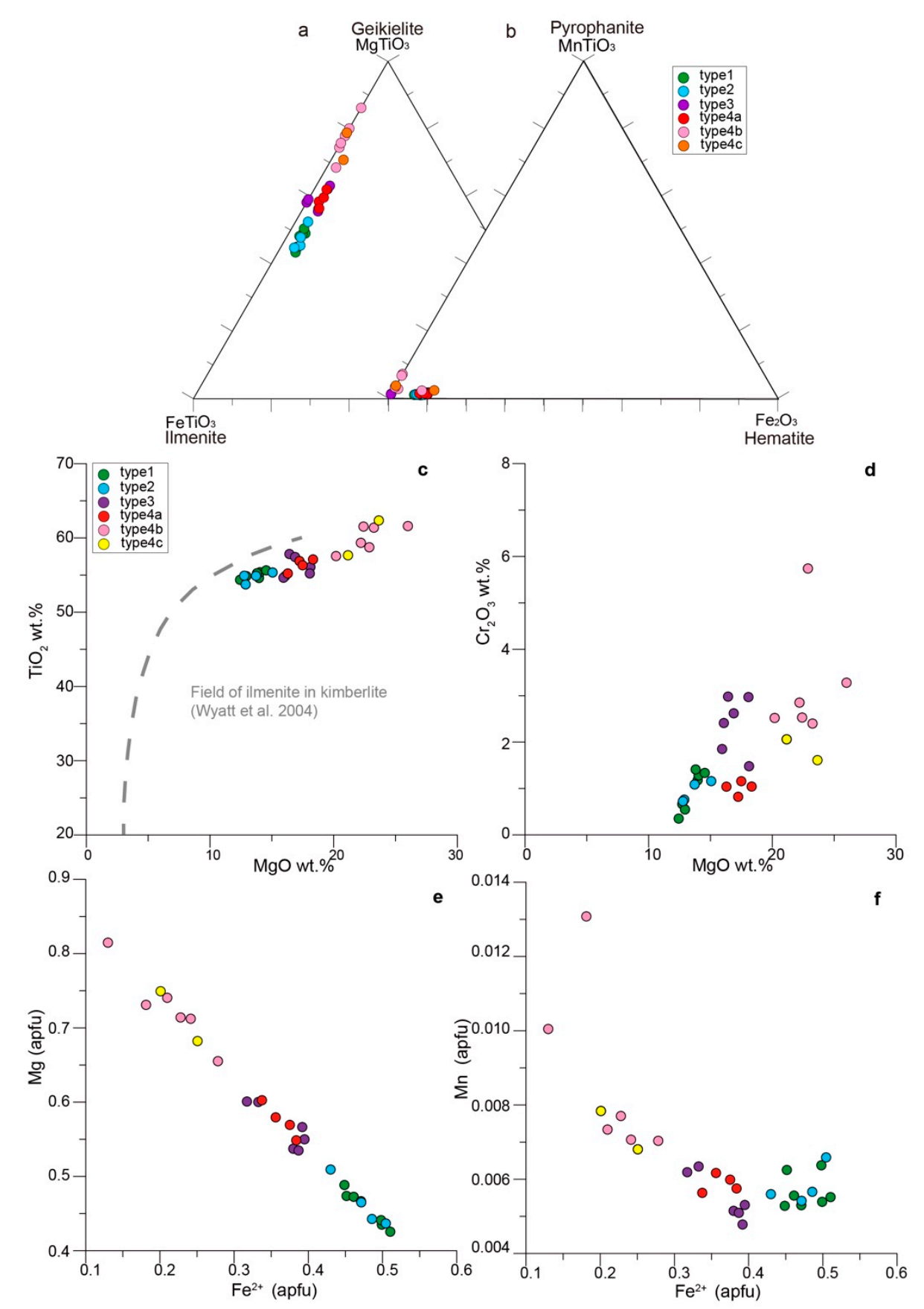

Figure 5. Composition of ilmenite-group minerals. Ternary plots of the different textural types (1 to 4) of ilmenite from Menominee: (a) in terms of the geikielite $\left(\mathrm{MgTiO}_{3}\right)$-ilmenite $\left.(\mathrm{FeTiO})_{3}\right)$-hematite $\left(\mathrm{Fe}_{2} \mathrm{O}_{3}\right)$; (b) in terms of the pyrophanite $\left(\mathrm{MnTiO}_{3}\right)$-ilmenite $\left(\mathrm{FeTiO}_{3}\right)$-hematite $\left(\mathrm{Fe}_{2} \mathrm{O}_{3}\right)$ end members. Binary plots between the major elements analyzed in different types of ilmenite-group minerals described in the main text $(\mathbf{c}-\mathbf{f})$.

The representative results of the analyses of rutile (Table 2) are plotted in Figure 6. The three textural types of rutile have similar compositions: $0.9-2.0$ wt. $\% \mathrm{Nb}_{2} \mathrm{O}_{5}, 0.8-4.5$ wt. $\% \mathrm{Cr}_{2} \mathrm{O}_{3}$, and 0.6-0.9 wt.\% $\mathrm{V}_{2} \mathrm{O}_{3}$. Nevertheless, the $\mathrm{Cr}_{2} \mathrm{O}_{3}$ content decreases from type 1 (up to $4.5 \mathrm{wt} . \%$ ), to type 2 (up to $3.0 \mathrm{wt} . \%$ ) and to type 3 (up to $1.2 \mathrm{wt} . \%$ ). With regard to $\mathrm{Nb}$, type 1 rutile has up to $2.0 \mathrm{wt} . \% \mathrm{Nb}_{2} \mathrm{O}_{5}$, type 2 has up to $1.7 \mathrm{wt} . \%$, and type 3 has up to $1.2 \mathrm{wt} . \%$. In the $\mathrm{TiO}_{2}-\mathrm{Cr}_{2} \mathrm{O}_{3}$ plot, most of the rutile crystals show kimberlite groundmass compositions, as in [24]. On the other hand, the range also matches the composition of rutile from cratonic, deep-seated magmatic rocks (Figure 6a). 
The $\mathrm{Cr}_{2} \mathrm{O}_{3}-\mathrm{Nb}_{2} \mathrm{O}_{5}$ plot (Figure $6 \mathrm{~b}$ ) shows both in the fields of xenogenic material and pyrope inclusions and outside the field of rutile from metasomatic nodules.
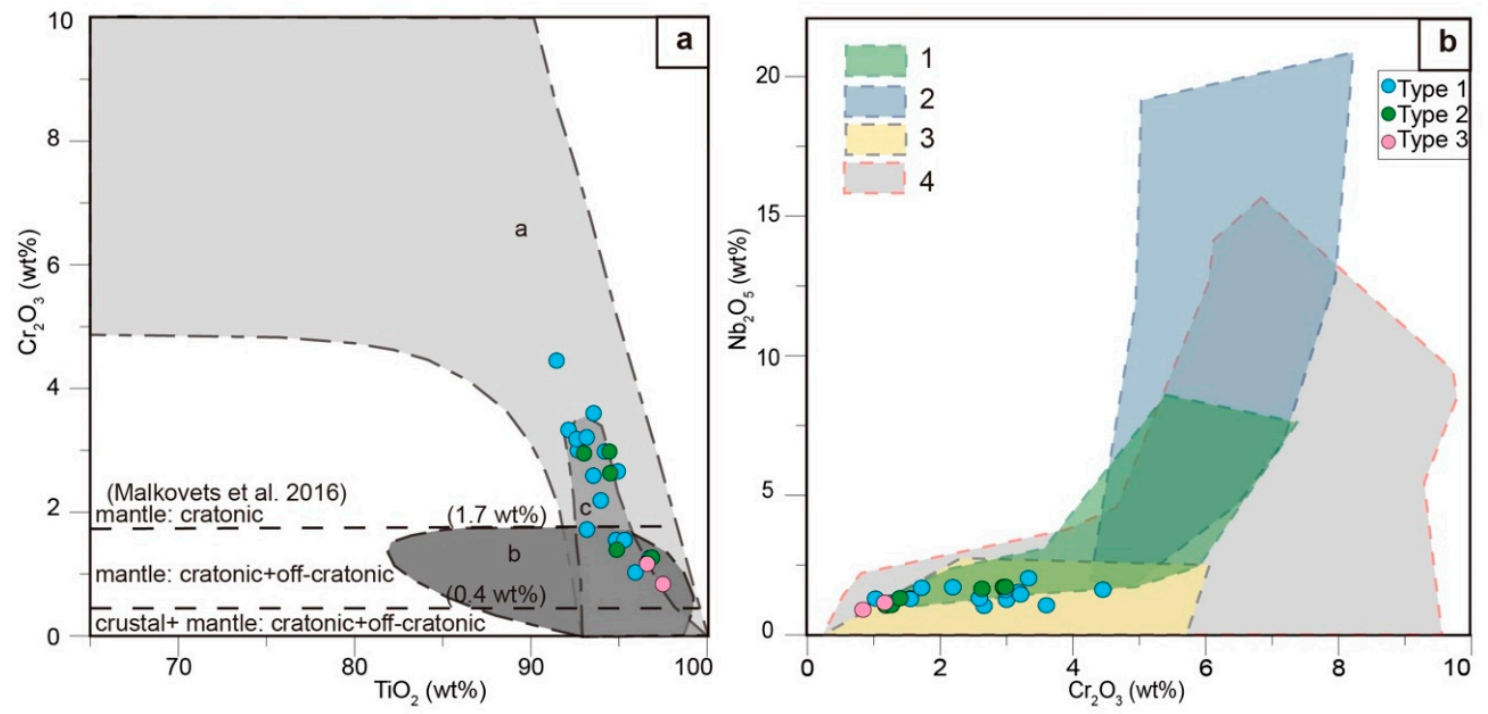

Figure 6. Chemical composition of the three different rutile types described in this work for the studied Menominee samples. (a) $\mathrm{TiO}_{2}-\mathrm{Cr}_{2} \mathrm{O}_{3}$ plot (composition fields are according to [24]). Domain labeled " $a$ " corresponds to rutile from cratonic deep-seated magmatic rocks, domain " $b$ " to rutile from off-craton alkali basalts, and domain "c" to groundmass rutile from kimberlites. (b) $\mathrm{Cr}_{2} \mathrm{O}_{3}-\mathrm{Nb}_{2} \mathrm{O}_{5}$ plot. Domain labeled 1 corresponds to rutile from the xenogenic material of kimberlites of South Africa [25]; domain 2 to rutile in metasomatic nodules from the kimberlites of the Orapa pipe, Botswana [25]; domain 3 to rutile inclusions in pyrope from Garnet Ridge [26]; and domain 4 to rutile inclusions in pyrope from the Internatsionalnaya pipe [27].

The composition of our djerfisherite is shown in Table 3. Djerfisherite is Ni-rich (5.5-7.9 apfu Ni) and $\mathrm{Cu}$-poor (0.4-1.2 apfu $\mathrm{Cu}$ ). Its average structural formula is $\left[\mathrm{K}_{5.86} \mathrm{Na}_{0.03} \mathrm{Ca}_{0.03}\right]$ $\left[\mathrm{Fe}_{17.46} \mathrm{Ni}_{6.64} \mathrm{Cu}_{0.80} \mathrm{Co}_{0.15}\right] \mathrm{S}_{26} \mathrm{Cl}_{1.00}$. The composition of the djerfisherite is compared with other worldwide occurrences in Figure 7.

Table 3. Representative analyses of djerfisherite.

\begin{tabular}{|c|c|c|c|c|c|c|}
\hline Sample & 9352-B_dj & 9352-B_dj & 9352-B_dj & 9352-U_dj & 9352-R_dj & 9352-R_dj \\
\hline No. & $\# 3$ & $\# 4$ & \#6 & $\# 17$ & $\# 26$ & \#28 \\
\hline \multicolumn{7}{|l|}{ wt. $\%$} \\
\hline $\mathrm{Si}$ & 0.03 & bdl & bdl & bdl & bdl & 0.02 \\
\hline $\mathrm{Al}$ & 0.01 & bdl & 0.02 & 0.02 & 0.01 & 0.01 \\
\hline $\mathrm{Ca}$ & 0.04 & bdl & 0.02 & 0.06 & 0.04 & 0.03 \\
\hline K & 8.99 & 8.85 & 8.83 & 8.95 & 8.99 & 8.93 \\
\hline $\mathrm{Mg}$ & bdl & 0.03 & bdl & bdl & bdl & 0.02 \\
\hline $\mathrm{Na}$ & 0.03 & bdl & 0.07 & 0.07 & 0.05 & bdl \\
\hline $\mathrm{Cu}$ & 1.23 & 1.31 & 1.16 & 3.04 & 1.61 & 2.05 \\
\hline $\mathrm{Ni}$ & 16.61 & 16.33 & 16.42 & 12.96 & 18.33 & 17.77 \\
\hline Co & 0.52 & 0.48 & 0.51 & 0.16 & 0.27 & 0.24 \\
\hline $\mathrm{Fe}$ & 37.98 & 37.85 & 38.06 & 39.01 & 35.68 & 35.64 \\
\hline $\mathrm{Pb}$ & 0.33 & 0.35 & 0.36 & 0.32 & 0.36 & 0.32 \\
\hline$S$ & 32.69 & 32.60 & 32.61 & 32.63 & 32.65 & 32.66 \\
\hline $\mathrm{Cl}$ & 1.36 & 1.39 & 1.39 & 1.38 & 1.39 & 1.41 \\
\hline Total & 99.82 & 99.20 & 99.45 & 98.60 & 99.37 & 99.10 \\
\hline
\end{tabular}


Table 3. Cont

\begin{tabular}{ccccccc}
\hline Sample & 9352-B_dj & 9352-B_dj & 9352-B_dj & 9352-U_dj & 9352-R_dj & 9352-R_dj \\
\hline No. & \#3 & \#4 & \#6 & \#17 & \#26 & \#28 \\
\hline apfu & \multicolumn{7}{c}{ Cations on the basis of 26 S } \\
\hline $\mathrm{Si}$ & 0.03 & 0.00 & 0.00 & 0.00 & 0.00 & 0.01 \\
$\mathrm{Al}$ & 0.01 & 0.00 & 0.01 & 0.02 & 0.01 & 0.01 \\
$\mathrm{Ca}$ & 0.03 & 0.00 & 0.01 & 0.04 & 0.03 & 0.02 \\
$\mathrm{~K}$ & 5.86 & 5.79 & 5.77 & 5.85 & 5.87 & 5.83 \\
$\mathrm{Mg}$ & 0.00 & 0.03 & 0.00 & 0.00 & 0.00 & 0.02 \\
$\mathrm{Na}$ & 0.03 & 0.00 & 0.07 & 0.08 & 0.05 & 0.00 \\
$\mathrm{Cu}$ & 0.49 & 0.53 & 0.47 & 1.22 & 0.65 & 0.82 \\
$\mathrm{Ni}$ & 7.22 & 7.12 & 7.15 & 5.64 & 7.97 & 7.73 \\
$\mathrm{Co}$ & 0.23 & 0.21 & 0.22 & 0.07 & 0.12 & 0.10 \\
$\mathrm{~Pb}$ & 0.04 & 0.04 & 0.04 & 0.04 & 0.04 & 0.04 \\
$\mathrm{Fe}$ & 17.34 & 17.33 & 17.42 & 17.85 & 16.31 & 16.29 \\
$\mathrm{~S}$ & 26.00 & 26.00 & 26.00 & 26.00 & 26.00 & 26.00 \\
$\mathrm{Cl}$ & 0.98 & 1.00 & 1.00 & 0.99 & 1.00 & 1.02 \\
\hline
\end{tabular}

bdl: below detection limit.
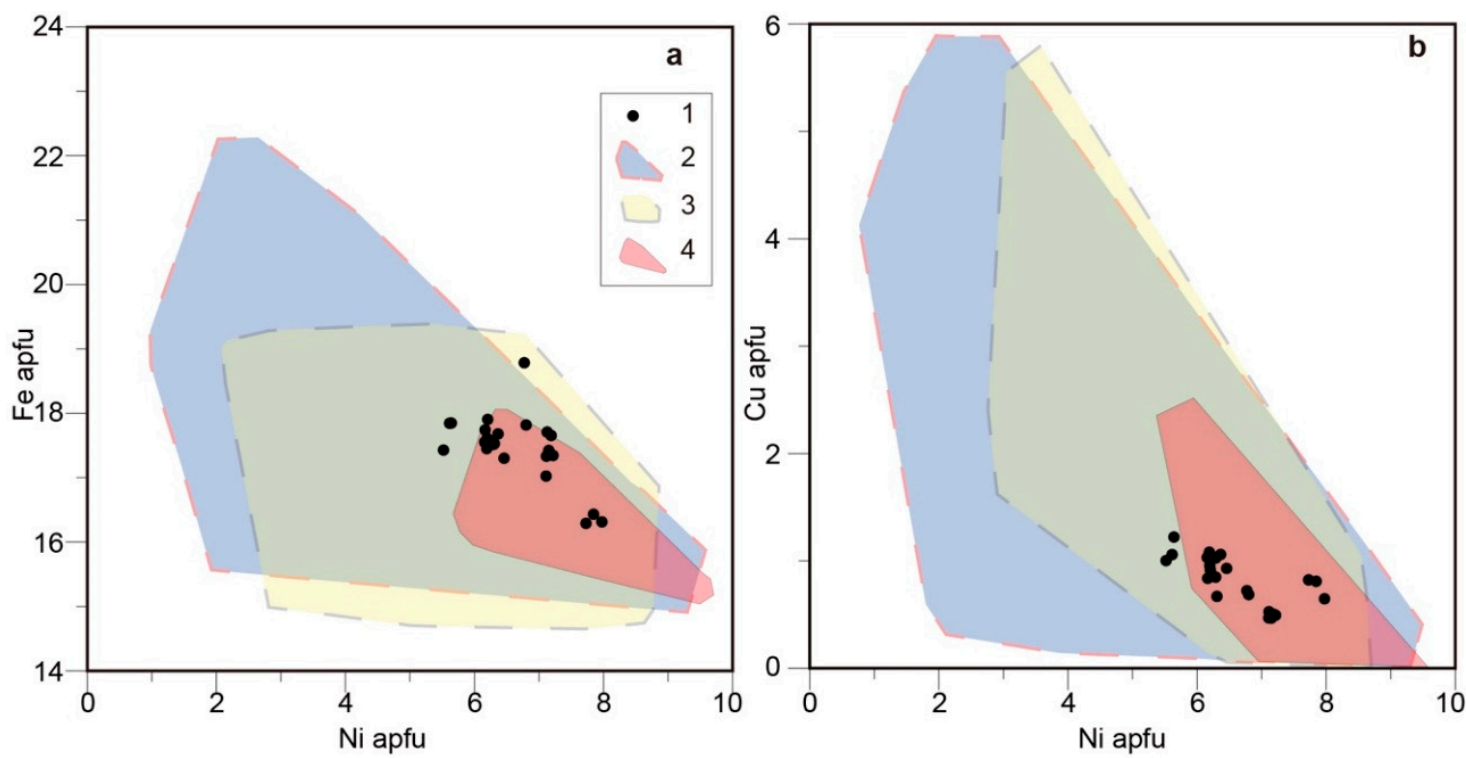

Figure 7. Diagrams showing the composition of djerfisherite. (a) Ni vs. Fe and (b) Ni vs. Cu plots; 1, djerfisherite from the groundmass of the site 73 Menominee kimberlite (this work); 2, djerfisherite from kimberlite groundmass and from melt inclusions in kimberlitic olivine from the Udachnaya-East pipe [28,29]; 3, djerfisherite from xenoliths from the Siberian kimberlites [29-34]; 4, djerfisherite from sulfide inclusions in the Siberian diamonds [30,35].

\section{The U-Pb Age of Rutile}

Four analyses were conducted in situ on a microcryst of rutile (textural type 2). The uranium contents varied from 5.2 to $5.5 \mathrm{ppm}$, and the Th/U values were consistent and equal to 0.05 . The measured ${ }^{207} \mathrm{~Pb} /{ }^{206} \mathrm{~Pb}$ of four spots was in range of 0.08 to 0.14 , corresponding to $\mathrm{f}_{206}$ (the percentage of common ${ }^{206} \mathrm{~Pb}$ in total ${ }^{206} \mathrm{~Pb}$ ), around $4 \%$ to $12 \%$. The regression line with these rather clustered data gives an imprecise upper intercept of $2.4 \pm 2.8$ as the common $\mathrm{Pb}$ composition, which is obviously unreasonable. An anchored composition of common $\mathrm{Pb}$ expressed by the ratio ${ }^{207} \mathrm{~Pb} /{ }^{206} \mathrm{~Pb}$ as $0.84 \pm 0.05$ assigned as the SK (Stacey and Kramers) model [36] was used. The regression line derived from the data points on the Tera-Wasserburg (TW) plot (mean standard weighted deviation MSWD $=1.06$ ) shows a lower intercept age of $168.9 \pm 4.4 \mathrm{Ma}$ (Figure 8 and Table 4 ). According to the 
evaluation of the variation in common $\mathrm{Pb}$ composition, the influence on the final age from common $\mathrm{Pb}$ should be less than $1 \%$. The main uncertainty is from the $\mathrm{Pb} / \mathrm{U}$ elemental instrumental fractionation and statistical counting error.

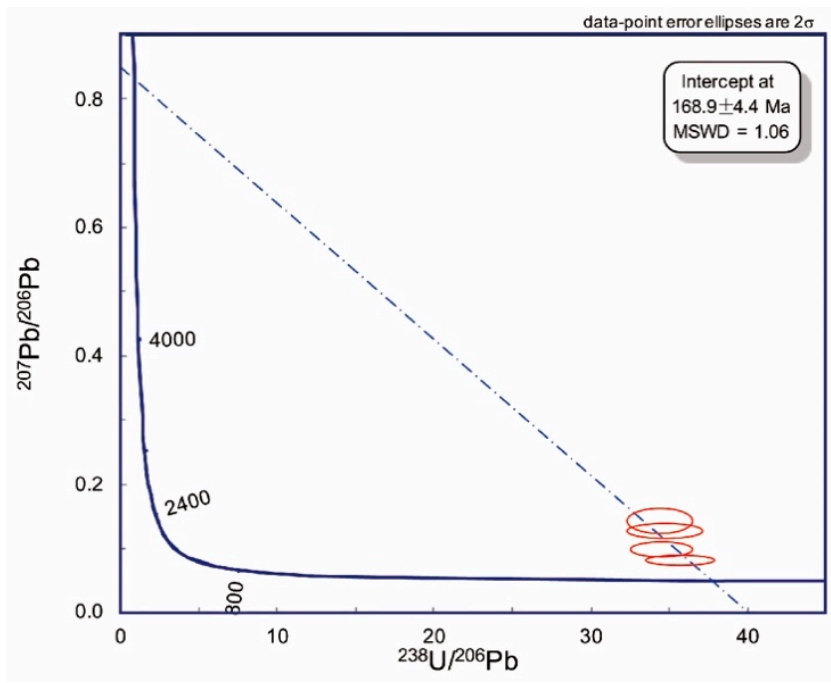

Figure 8. $\mathrm{U}-\mathrm{Pb}$ age concordia diagram for rutile from the site 73 Menominee kimberlite.

Table 4. Rutile U-Pb data analyzed by a CAMECA IMS 1280HR ion microprobe.

\begin{tabular}{|c|c|c|c|c|c|c|c|c|c|c|}
\hline \multirow{2}{*}{ Analysis } & \multirow{2}{*}{$\begin{array}{c}\mathrm{U} \\
\mathrm{ppm}\end{array}$} & \multirow[t]{2}{*}{$\mathrm{Th} / \mathrm{U}$} & \multicolumn{4}{|c|}{ TW Concordia Columns (Uncorrect) } & \multicolumn{3}{|c|}{${ }^{207} \mathrm{~Pb}$ Correction } & \multirow[t]{2}{*}{$f_{206}$} \\
\hline & & & ${ }^{238} \mathrm{U} /{ }^{206} \mathrm{~Pb}$ & Error $(\%)$ & ${ }^{207} \mathrm{~Pb} /{ }^{206} \mathrm{~Pb}$ & Error $(\%)$ & & Age (Ma) & Error (Ma) & \\
\hline 9352-D_rt@1 & 5.5 & 0.051 & 34.40 & 2.5 & 0.1424 & 5.7 & 0.12 & 164 & 6 & 0.12 \\
\hline 9352-D_rt@2 & 5.3 & 0.051 & 34.72 & 2.9 & 0.1262 & 3.8 & 0.10 & 166 & 6 & 0.10 \\
\hline 9352-D_rt@3 & 5.2 & 0.052 & 34.47 & 2.4 & 0.0983 & 5.3 & 0.06 & 173 & 5 & 0.06 \\
\hline 9352-D_rt@4 & 5.2 & 0.051 & 35.68 & 2.6 & 0.0817 & 4.1 & 0.04 & 171 & 5 & 0.04 \\
\hline
\end{tabular}

\section{Discussion}

\subsection{Paragenetic Sequence}

The fresh samples from the site 73 Menominee kimberlite allow us to propose a complete paragenetic sequence (Figure 9) and reconstruct the petrogenetic history of kimberlite magma. We interpret the Mg-rich ilmenite of textural types 1 and 2 and the olivine cores (O11) with inclusions of pentlandite and pyrrhotine to be xenocrysts of mantle formation. Olivine Ol1 has a composition typical of mantle peridotite, whereas the Mg-rich ilmenite is a typical mineral formed during a metasomatic process in the source [37]. These xenocrysts of olivine and ilmenite are replaced or mantled by minerals that crystallized from kimberlitic magma. Subhedral rutile crystallized at the early stage of growth of the first forsterite rim (Ol2), whereas geikielite and spinel s.s. started to crystallize during the late stage of the growth of that rim. Rutile in kimberlitic rocks is commonly interpreted as being xenocrystic, derived from the disaggregation of a wide variety of rocks either of crustal or mantle origin (eclogites, MARID (Mica-Amphibole-Rutile-Ilmenite-Diopside), pyroxenites, and metasomatized peridotites) $[25,38]$. On the other hand, rutile has been also described as inclusions within or intergrown with diamond [25,38]. Its composition is broadly used to constrain the source rock. Chromium-poor rutile is interpreted to be derived from both crustal and off-cratonic or cratonic mantle rocks, whereas $\mathrm{Cr}$-rich rutile $\left(>1.7 \mathrm{wt} . \% \mathrm{Cr}_{2} \mathrm{O}_{3}\right)$ is considered to be exclusively related to cratonic mantle [24]. Rutile derived from metasomatized mantle-derived xenoliths may contain up to 9.75 wt. \% $\mathrm{Cr}_{2} \mathrm{O}_{3}[25,26]$. These determinations and the potential for $\mathrm{U}-\mathrm{Pb}$ dating have categorized mantle rutile as a diamond indicator mineral (e.g., [24]). Although the rutile crystals studied here are found mostly in the cratonic mantle compositional field, they occur as subhedral inclusions in growth 
bands in zoned olivine (O12). Therefore, these crystals can hardly be described as being xenocrystic. Moreover, the composition of the rutile microcrysts is the same as the composition of rutile inclusions in olivine. Hence, we suggest that all these rutile crystals formed during the early stages of magma crystallization, prior to the crystallization of the first rim on olivine (Ol2). This was followed by the crystallization of geikielite and spinel s.s. As a consequence, the occurrence of phenocrystic rutile in Menominee precludes the use of the aforementioned rutile-based diagrams unless previous accurate petrographic study ensures that the rutile crystals are xenocrysts. In any case, all the rutile types tend to be replaced by geikielite (ilmenite-group mineral 4), which also replaces the above categories of ilmenite. The composition of the replacing ilmenite in terms of minor elements inherits the composition of the replaced minerals, as noted in other kimberlites [37,39].

\begin{tabular}{|c|c|c|c|c|c|c|}
\hline \multirow[b]{2}{*}{ Olivine 1} & \multirow{2}{*}{ Mantle } & \multicolumn{2}{|c|}{ Magma 1} & \multirow[t]{2}{*}{ Mingling } & \multirow[t]{2}{*}{ Magma 2} & \multirow[t]{2}{*}{ Hydrothermal } \\
\hline & & & & & & \\
\hline Pentlandite & & & & & & \\
\hline Pyrrhotite & D. & & & & & \\
\hline IImenite 1, 2 (Mg-rich) & & & & & & \\
\hline Rutile1,2,3 & & & & & & \\
\hline IImenite 3 (Geikielite) & & $\longrightarrow$ & & & & \\
\hline Olivine 2 & & & & & & \\
\hline IImenite 4a (Geikielite) & & $--=$ & & & & \\
\hline IImenite 4b (Geikielite) & & $=-$ & $----\cdot$ & & & \\
\hline IImenite 4c (Geikielite) & & $=-$ & $----\cdot$ & & & \\
\hline Spinel s.s. & & & & & & \\
\hline Olivine 3 & & & & & & \\
\hline Djerfisherite & & & & & & \\
\hline Calcite & & & & & & \\
\hline MUM & & & & & & \\
\hline Dolomite & & & & & & \\
\hline Barite & & & & & & \\
\hline Meixnerite & & & & & & \\
\hline
\end{tabular}

Figure 9. Paragenetic sequences of the crystallization of minerals in site 73 Menominee kimberlites.

The site 73 kimberlite emplacement age has been estimated to be 155 Ma using zircon fission-track dating and $190 \mathrm{Ma}$ using K-Ar of phlogopite [8]. However, these two estimates derive from a personal communication based on analyses from 1987, providing only two numbers of age without any analysis dates. Moreover, the closure temperature of the zircon fission-track is about $220^{\circ} \mathrm{C}$, which is easily affected by the later modification; thus, the age obtained by this method is usually lower. The $\mathrm{K}-\mathrm{Ar}$ method may be uncertain because of the heterogeneous element content of the sample or the excess Ar; thus, the age obtained by this method is usually higher. Therefore, the U-Pb system of stable mineral rutile was selected in this work to determine the emplacement age. The rutile from Menominee was dated by SIMS U-Pb dating at $168.9 \pm 4.4 \mathrm{Ma}$. This age is broadly consistent with the 155 and $190 \mathrm{Ma}$ reported earlier in [8], and also with the nearby Lake Ellen kimberlite at 186 $\pm 6,190 \pm 5$ (unpublished data in [10]), and $266 \pm 9 \mathrm{Ma}[11]$.

\subsection{Magma Mingling Revealed by the Coexistence of Two Spinels in the Groundmass}

The coexistence of two different spinel-group minerals (spinel s.s. and qandilite-rich MUM) in the groundmass of the Menominee kimberlite samples provides evidence for the mingling of two magmas, each spinel crystallizing from a separate immiscible magma. Magma mingling is not rare and has also been invoked to explain the simultaneous occurrence of two types of perovskite in groundmass $[5,40]$. The study of the mineral sequence points to rather coeval spinels formed at the stage of groundmass crystallization.

Qandilite-rich MUM is found in the groundmass of some Michigan kimberlites, such as Menominee and Lake Ellen [41]. Although the crystals have variable compositions (28-56 mol.\% of the qandilite component), the highest magnesium content is found in the MUM replacing geikielite. However, 
the occurrence of a MUM spinel replacing geikielite is very common in kimberlites, without achieving such magnesium enrichment. Therefore, the occurrence of groundmass qandilite-rich MUM indicates the existence of a high activity of $\mathrm{Mg}$ in the magma:

$$
\mathrm{MgTiO}_{3}+\mathrm{MgO} \rightarrow \mathrm{Mg}_{2} \mathrm{TiO}_{4}
$$

The presence of spinel s.s. in the groundmass of a kimberlite is relatively rare, although not unknown (Igwisi [21,42] and Tli Kwi Cho [21]). The early crystallization of aluminous spinels in a kimberlite groundmass has been attributed to the absence of phlogopite crystallization [21,43].

Spinel s.s. is found in the groundmass of some lamprophyres, as in polzenite and melilitolite from the Ploučnice River region, Czechoslovakia [44]. However, in the Czech case, the spinel is zoned and has a Ti-rich rim of MUM type. Here, the higher Al content of the magma can account for the occurrence of spinel s.s. It is also found as an inclusion in leucite in the West Kimberly lamproite $[45,46]$; the authors attributed these crystals to exsolution from a non-stoichiometric leucite containing $\mathrm{Mg}$, $\mathrm{Fe}$, and $\mathrm{Ti}$ in solid solution. They argued that the exsolution could be favored by undercooling. However, it can be argued that the undercooling would favor exactly the contrary-the preservation of metastable high-T phases. The exsolution hypothesis is ruled out in the present case because of textural evidence and paragenetic position: both spinels occur as abundant euhedral crystals in the groundmass, and each term tends to be associated with different minerals. Moreover, the $\mathrm{Al} / \mathrm{Ti}$ contents in spinels have been used to constrain the activity of these elements in the original magma; these proportions are different depending on the source of the magma [47]. Hence, the occurrence of two different spinels can be indicative of different magmas from different sources.

The crystallization of djerfisherite in the Menominee kimberlite could produce the depletion of $\mathrm{K}$ in the magma and therefore favor the crystallization of spinel. However, djerfisherite formed at a relatively late phase in this kimberlite, whereas spinel formed at an early stage. Djerfisherite occurrences in kimberlites worldwide are generally late to form, resulting from the replacement of early-formed sulfides [48]. The early crystallization of spinel s.s. could produce the depletion of Al in the magma, which favors the crystallization of K sulfides rather than phlogopite.

By assuming that these two spinels were produced by the crystallization of two different magmas, we next questioned the nature of the two magmas. The two spinels are unzoned, and they do not follow the typical trends described of kimberlites; the Igwisi [21,42] and Tli Kwi Cho kimberlites [21] are exceptional. The early crystallization of an aluminum spinel in a kimberlite groundmass has been explained as a result of the lack of the phlogopite crystallization [21,43]. Some authors [21] suggested that the trend from chromite to aluminous spinel is the result of rapid growth at a high degree of supersaturation of spinel. However, a chromite core has not been found in the crystals of spinel s.s. in our samples. Rather, the occurrence of qandilite-rich MUM spinel at the last stages of magma crystallization might indicate the existence of a highly evolved kimberlitic magma, such as that mentioned for the Jos and Benfontein kimberlites [1]. However, MUM is found in contact with dolomite at site 73. Qandilite-rich spinel associated with a dolomitic groundmass is also known in a kimberlite sill at Wemindji, Quebec (Canada) [44]. Similar compositions of qandilite-rich MUM were found in association with carbonates in the kimberlite groundmass at the Igwisi Hills and Benfontein $[42,49]$. This assemblage is consistent with the expected conditions of the crystallization of qandilite, favored by extremely high $f\left(\mathrm{CO}_{2}\right)$ and extremely low a $\left(\mathrm{SiO}_{2}\right)$ [50]. We believe that the mingling of an immiscible dolomite-rich melt (magma 2) might have led to the crystallization of dolomite and qandilite. Qandilite-rich MUM and dolomite appear as late minerals in the crystallization sequence. We propose an injection of a carbonatite magma rich in the dolomite component during the crystallization of the kimberlitic magma. 


\subsection{Volatiles in the Kimberlitic Melt}

We next considered another important observation-the occurrence of a complex alkali- and chlorine-bearing sulfide such as djerfisherite. It is found in several geological environments-e.g., Si-poor igneous rocks, meteorites [51], carbonatites [52,53], kimberlites [29,54,55], metasomatized mantle rocks [56], melt inclusions in basaltic rocks [57], and ultramafic lamprophyres [58]. Djerfisherite is also found in chloride-carbonate "nodules" in kimberlite [4]. In mantle xenoliths, it rims $\mathrm{Fe}-\mathrm{Ni}-\mathrm{Cu}$ sulfides and sulfide globules [29-34,59], is a daughter phase in melt inclusions [28,30-32,35,59-63], and occurs as an inclusion in diamonds [35]. However, experimental data indicated that djerfisherite is not stable at pressures greater than $3 \mathrm{Gpa}$ [63]. Thus, the djerfisherite included in diamond and mantle xenoliths could not have crystallized in the cratonic lithospheric mantle [64], but might have formed by interaction between xenoliths and a kimberlite melt $[64,65]$. Some authors proposed that djerfisherite formed as a replacement product of pre-existing $\mathrm{Fe}-\mathrm{Ni}-\mathrm{Cu}$ xenolithic sulfides by a $\mathrm{K}-\mathrm{Cl}$ bearing melt or by the direct crystallization of the kimberlite melt [66]. A late magmatic origin of djerfisherite, at a shallow depth and at less than $800^{\circ} \mathrm{C}$, was also suggested to explain the occurrence of this mineral in the groundmass of the Udachnaya-East kimberlite [29]. The same has been suggested for the groundmass djerfisherite from the Lac de Gras field [67]. Finally, the presence of djerfisherite might indicate a $\mathrm{Cl}$ enrichment in the kimberlite melt, as djerfisherites described in Udachnaya-East and Kuoikskoe kimberlites [29,64]. The groundmass djerfisherite in the Udachnaya-East kimberlite is not contaminated by crustal components, as indicated by S isotopes, which are within the mantle range and are thus primary [68]. These authors proposed that djerfisherite crystallized at the late stage of the kimberlite evolution, during the eruption, when the evolved kimberlitic magma became sufficiently enriched in $\mathrm{S}, \mathrm{Na}, \mathrm{K}$, and $\mathrm{Cl}$ [68]. A potassium-enriched upper mantle at $120-140 \mathrm{~km}$ is proposed by the study of xenoliths from the nearby Lake Ellen kimberlite [12]. The occurrence of djerfisherite at Menominee indicates a high activity of volatiles ( $\mathrm{S}$ and $\mathrm{Cl}$ ) and alkalis during melt crystallization, as well as a low Si activity, which could also explain the common occurrence of spinel s.s. instead of phlogopite. The higher volatile content probably led to more rapid eruption, thus favoring the preservation of diamond [40]. The occurrence of djerfisherite in kimberlite also provides evidence that the melt was enriched in alkalis and halogens $[29,64,66]$.

\section{Conclusions}

A petrographic examination of rock samples from Menominee revealed a complex paragenetic sequence that strongly suggests the injection of a magnesiocarbonatitic liquid into a resident kimberlitic melt. We attribute the coexistence of two spinel-group minerals in the Menominee kimberlite groundmass to the mingling of two magmas. Spinel s.s. likely crystallized from the kimberlitic melt, whereas qandilite-rich MUM crystallized from the carbonate melt. The crystallization of spinel s.s. instead of phlogopite in the groundmass is consistent with the low activity of Si in this kimberlitic melt. The occurrence of djerfisherite microcrysts as an accessory phase indicates a high activity of volatile elements $(\mathrm{Cl}$ and $\mathrm{S})$ during the late stages of the crystallization of the magma. The emplacement of the Menominee kimberlite occurred at 168.9 $\pm 4.4 \mathrm{Ma}$, according to the U-Pb data for a rutile microphenocryst.

Author Contributions: Conceptualization, J.X. and J.C.M.; methodology, J.X.; investigation, J.X., J.C.M., Q.L., M.C.-O, L.T.i.A.; writing-original draft preparation, J.X. and J.C.M.; writing-review and editing, J.X., J.C.M., Q.L., M.C.-O., L.T.i.A.; funding acquisition, J.C.M., Q.L. All authors have read and agreed to the published version of the manuscript.

Funding: This work was supported by the National Key Research and Development Program of China (2016YFE0203000), the National Natural Science Foundation of China (41773044 and 41673059), China Postdoctoral Science Foundation (grant number 2020M670447), and Open Fund Project (number SKL-K202001) from the State Key Laboratory of Lithospheric Evolution, Institute of Geology and Geophysics, Chinese Academy of Sciences, grant numbers CGL2006-12973 and CGL2009-13758 by Ministerio de Ciencia e Innovación (Spain), the 2017 SGR 0707 of the AGAUR-Generalitat de Catalunya, and a FI grant to Jingyao Xu (coded FI_B 00904), sponsored by the Secretaria d'Universitats i Recerca del Departament d'Economia i Coneixement de la Generalitat de Catalunya. 
Acknowledgments: The authors acknowledge the thin section preparation laboratory and the Scientific and Technological Centers of the University of Barcelona (CCiTUB) for the assistance with the SEM-BSE-EDS study (Javier García-Veigas, David Artiaga) and EMP analyses (Xavier Llovet). We also thank Hongxia Ma for preparing sample mounts, and the engineers (Guo-Qiang Tang, Yu Liu, Xiaoxiao Ling and Jiao Li) for the SIMS analyses. We would like to thank the four anonymous reviewers for their comments to improve this manuscript.

Conflicts of Interest: The authors declare no conflict of interest.

\section{References}

1. Mitchell, R.H. Kimberlites: Mineralogy, Geochemistry, and Petrology; Plenum Press: New York, NY, USA, 1986.

2. Yang, Y.H.; Wu, F.Y.; Wilde, S.A.; Liu, X.M.; Zhang, Y.B.; Xie, L.W.; Yang, J.H. In situ perovskite Sr-Nd isotopic constraints on the petrogenesis of the Ordovician Mengyin kimberlites in the North China Craton. Chem. Geol. 2009, 264, 24-42. [CrossRef]

3. $\mathrm{Xu}, \mathrm{J} . ;$ Melgarejo, J.; Castillo-Oliver, M. Styles of alteration of Ti oxides of the kimberlite groundmass: Implications on the petrogenesis and classification of kimberlites and similar rocks. Minerals 2018, 8, 51. [CrossRef]

4. Kamenetsky, V.S.; Golovin, A.V.; Maas, R.; Giuliani, A.; Kamenetsky, M.B.; Weiss, Y. Towards a new model for kimberlite petrogenesis: Evidence from unaltered kimberlites and mantle minerals. Earth Sci. Rev. 2014, 139, 145-167. [CrossRef]

5. Castillo-Oliver, M.; Galí, S.; Melgarejo, J.C.; Griffin, W.L.; Belousova, E.; Pearson, N.J.; Watangua, M.; O'Reilly, S.Y. Trace-element geochemistry and U-Pb dating of perovskite in kimberlites of the Lunda Norte province (NE Angola): Petrogenetic and tectonic implications. Chem. Geol. 2016, 426, 118-134. [CrossRef]

6. Smith, B.S.; Nowicki, T.E.; Russell, J.K.; Webb, K.J.; Mitchell, R.H.; Hetman, C.M.; Harder, M.; Skinner, E.M.W.; Robey, J.A. Kimberlite Terminology and Classification. In Proceedings of the 10th International Kimberlite Conference, Bangalore, India, 6-11 February 2012; Pearson, D.G., Grütter, H.S., Harris, J.W., Kjarsgaard, B.A., O'Brien, H., Chalapathi Rao, N.V., Sparks, S., Eds.; Springer: New Delhi, India, 2013; Volume 2, pp. 1-17.

7. Sparks, R.S.J. Kimberlite Volcanism. Annu. Rev. Earth Planet. Sci. 2013, 41, 497-528. [CrossRef]

8. Jarvis, W.; Kalliokoski, J. Michigan kimberlite province. In Proceedings of the 34th Annual Institute on Lake Superior Geology, Proceedings and Abstracts, Marquette, MI, USA, 12-13 May 1988; Klasner, J., Ed.; Marquette: Milwaukee, WI, USA, 1988; Volume 43, pp. 46-48.

9. Jarvis, W. Michigan Kimberlites: An Update. In Proceedings of the 61st Annual Meeting; Prospectors \& Developers Association of Canada: Toronto, ON, Canada, 1993; paper M-10; pp. 46-48.

10. Heaman, L.M.; Kjarsgaard, B.A.; Creaser, R.A. The timing of kimberlite magmatism in North America: Implications for global kimberlite genesis and diamond exploration. Lithos 2003, 71, 153-184. [CrossRef]

11. Paces, J.B.; Zartman, R.E.; Taylor, L.A.; Futa, K.; Kwak, L.M. Pb isotopic evidence for multiple episodes of lower crustal growth and modification in granulite nodules from superior Province, Michigan. In Proceedings of the Program with Abstracts, Geological Society of America Conference, Dallas, TX, USA, 27-29 December 1990; p. A119.

12. Mcgee, E.S.; Hearn, B.C. The Lake Ellen Kimberlite, Michigan, U.S.A. In Proceedings of the 3rd International Kimberlite Conference, Clermont Ferrand, France, September 1982; Kornprobst, J., Ed.; Elsevier Science Publishers B.V.: Amsterdam, The Netherlands, 1984; Volume 1, pp. 143-154.

13. Carlson, S.M.; Floodstrand, W. Part 4-Michigan Kimberlites and Diamond Exploration Techniques, Proceedings Institute on Lake Superior Geology 40th Annual Meeting, 11-14 May 1994; Michigan Technological University: Houghton, MI, USA, 1994; Volume 40, p. 15.

14. Robinson, G.W. Mineralogy of Michigan; Heinrich, E.W., Ed.; Seaman Mineral Museum: Houghton, MI, USA, 2004.

15. Fults, M.E. A Trace Element Geochemical Analysis of the Lake Ellen Kimberlite, Crystal Falls, Michigan, USA; Western Michigan University: Kalamazoo, MI, USA, 1987.

16. Carlson, S.M.; Adams, G.W. The diamondiferous Six-Pak ultramafic lamprophyre diatreme, Kenosha, Wisconsin. In Proceedings of the 43rd Annual Meeting of Institute on Lake Superior Geology, Sudbury, Ontario, Canada, 6-11 May 1997; Sage, R., Meyer, W., Eds.; Institute on Lake Superior Geology: Sudbury, ON, Canada, 1997; Volume 43, pp. 11-12.

17. Li, Q.; Lin, W.; Su, W.; Li, X.; Shi, Y.; Liu, Y.; Tang, G. SIMS U-Pb rutile age of low-temperature eclogites from southwestern Chinese Tianshan, NW China. Lithos 2011, 122, 76-86. [CrossRef] 
18. Li, Q.; Li, X.; Wu, F.; Liu, Y.; Tang, G. Accessary minerals SIMS U-Th-Pb dating for kimberlite and lamproite. Acta Geol. Sin. Engl. Ed. 2016, 90, 74-75. [CrossRef]

19. Zhou, T.; Li, Q.; Klemd, R.; Shi, Y.; Tang, X.; Li, C.; Liu, Y. Multi-system geochronology of North Dabie eclogite: Ineffective garnet 'shielding' on rutile inclusions under multi-thermal conditions. Lithos 2020, 368-369, 105573. [CrossRef]

20. Li, Q.L.; Yang, Y.N.; Shi, Y.H.; Lin, W. Eclogite rutile U-Pb dating: Constraint for formation and evolution of continental collisional orogen. Chin. Sci. Bull. 2013, 23, 2279-2284.

21. Roeder, P.L.; Schulze, D.J. Crystallization of groundmass spinel in kimberlite. J. Petrol. 2008, 49, $1473-1495$. [CrossRef]

22. Mitchell, R.H. Kimberlites, Orangeites, and Related Rocks; Plenum Press: New York, NY, USA, 1995.

23. Wyatt, B.A.; Baumgartner, M.; Anckar, E.; Grutter, H. Compositional classification of "kimberlitic" and "non-kimberlitic" ilmenite. Lithos 2004, 77, 819-840. [CrossRef]

24. Malkovets, V.G.; Rezvukhin, D.I.; Belousova, E.A.; Griffin, W.L.; Sharygin, I.S.; Tretiakova, I.G.; Gibsher, A.A.; O'Reilly, S.Y.; Kuzmin, D.V.; Litasov, K.D.; et al. Cr-rich rutile: A powerful tool for diamond exploration. Lithos 2016, 265, 304-311. [CrossRef]

25. Haggerty, S.E. Oxide mineralogy of the upper mantle. In Oxide Minerals: Petrologic and Magnetic Significance. Reviews in Mineralogy (Volume 25); Lindsey, D.H., Ed.; de Gruyter: New York, NY, USA, 1991; pp. 355-416.

26. Wang, L.; Essene, E.J.; Zhang, Y. Mineral inclusions in pyrope crystals from Garnet Ridge, Arizona, USA: Implications for processes in the upper mantle. Contrib. Mineral. Petrol. 1999, 135, 164-178. [CrossRef]

27. Rezvukhin, D.I.; Malkovets, V.G.; Sharygin, I.S.; Kuzmin, D.V.; Litasov, K.D.; Gibsher, A.A.; Pokhilenko, N.P.; Sobolev, N.V. Inclusions of $\mathrm{Cr}$ - and $\mathrm{Cr}-\mathrm{Nb}$-Rutile in pyropes from the Internatsionalnaya kimberlite pipe, Yakutia. Dokl. Earth Sci. 2016, 466, 173-176. [CrossRef]

28. Golovin, A.V.; Sharygin, V.V.; Pokhilenko, N.P. Melt inclusions in olivine phenocrysts in unaltered kimberlites from the Udachnaya-East pipe, Yakutia: Some aspects of kimberlite magma evolution during late crystallization stages. Petrology 2007, 15, 168-183. [CrossRef]

29. Sharygin, V.V.; Golovin, A.V.; Pokhilenko, N.P.; Kamenetsky, V.S. Djerfisherite in the Udachnaya-East pipe kimberlites (Sakha-Yakutia, Russia): Paragenesis, composition and origin. Eur. J. Mineral. 2007, 19, 51-63. [CrossRef]

30. Bulanova, G.P.; Spetsius, Z.V.; Leskova, N.V. Sulphides in Diamonds and Xenoliths from Yakutian Kimberlite Pipes (in Russian); Nauka: Novosibirsk, Russia, 1990.

31. Distler, V.V.; Ilupin, I.P.; Laputina, I.P. Sulfides of deep-seated origin in kimberlites and some aspects of copper-nickel mineralization. Int. Geol. Rev. 1987, 29, 456-464. [CrossRef]

32. Dobrovol'skaya, M.G.; Tsepin, A.I.; Ilupin, I.P.; Ponomarenko, A.I. Djerfisherite from Yakutia kimberlites. In Deposits, Minerals and parageneses of endogenic (In Russian); Tatarinov, P.M., Ed.; Nauka: Leningrad, Russia, 1975; pp. 3-11.

33. Misra, K.C.; Anand, M.; Taylor, L.A.; Sobolev, N.V. Multi-stage metasomatism of diamondiferous eclogite xenoliths from the Udachnaya kimberlite pipe, Yakutia, Siberia. Contrib. Mineral. Petrol. 2004, 146, 696-714. [CrossRef]

34. Solov'eva, L.V.; Barankevich, V.G.; Zav'yalova, L.L.; Lipskaya, V.I. Metasomatic alterations in ferromagnesian eclogites from the Udachnaya pipe. Dokl. Akad. Nauk. 1988, 303, 1450-1454.

35. Zedgenizov, D.A.; Logvinova, A.M.; Shatskii, V.S.; Sobolev, N.V. Inclusions in microdiamonds from some kimberlite diatremes of Yakutia. Dokl. Akad. Nauk. 1998, 359, 204-208.

36. Stacey, J.S.; Kramers, J.D. Approximation of terrestrial lead isotope evolution by a two-stage model. Earth Planet. Sci. Lett. 1975, 26, 207-221. [CrossRef]

37. Xu, J.; Melgarejo, J.C.; Castillo-Oliver, M. Ilmenite as a recorder of kimberlite history from mantle to surface: Examples from Indian kimberlites. Mineral. Petrol. 2018, 112, 569-581. [CrossRef]

38. Meinhold, G. Rutile and its applications in earth sciences. Earth Sci. Rev. 2010, 102, 1-28. [CrossRef]

39. Xu, J.; Melgarejo, J.C.; Castillo-Oliver, M.; Arqués, L.; Santamaria, J. Ilmenite generations in kimberlite from Banankoro, Guinea Conakry. Neues Jahrb. Miner. Abh. 2018, 195, 191-204. [CrossRef]

40. Ogilvie-Harris, R.C.; Field, M.; Sparks, R.S.J.; Walter, M.J. Perovskite from the Dutoitspan kimberlite, Kimberley, South Africa: Implications for magmatic processes. Mineral. Mag. 2009, 73, 915-928. [CrossRef]

41. $\mathrm{Xu}, \mathrm{J}$. Optimization of the Use of Diamond Indicator Minerals in Diamond Exploration in Kimberlites. Ph.D. Thesis, Universitat de Barcelona, Barcelona, Spain, 26 April 2019. 
42. Reid, A.M.; Donaldson, C.H.; Dawson, J.B.; Brown, R.W.; Ridley, W.I. The Igwisi Hills extrusive "kimberlites". Phys. Chem. Earth 1975, 9, 199-218. [CrossRef]

43. Pasteris, J.D. Spinel zonation of the De Beers kimberlite, South Africa: Possible role of phlogopite. Can. Mineral. 1983, 21, 41-58.

44. Ulrych, J.; Pivec, E.; Rutsek, J. Spinel zonation in melilite rocks of the Ploucnice river region, Czechoslovakia. Neues Jahrb. Miner. Abh. 1986, 155, 129-146.

45. Jaques, A.L.; Foley, S.F. The origin of Al-rich spinel inclusions in leucite from the leucite lamproites of Western Australia. Am. Mineral. 1985, 70, 11431150.

46. Mitchell, R.H.; Bergman, S.C. Petrology of Lamproites; Springer: Boston, MA, USA, 1991; ISBN 978-1-4613-6688-1.

47. Kamenetsky, V.S.; Crawford, A.J.; Meffre, S. Factors Controlling Chemistry of Magmatic Spinel: An Empirical Study of Associated Olivine, Cr-spinel and Melt Inclusions from Primitive Rocks. J. Petrol. 2001, 42, 655-671. [CrossRef]

48. Abersteiner, A.; Kamenetsky, V.S.; Goemann, K.; Giuliani, A.; Howarth, G.H.; Castillo-Oliver, M.; Thompson, J.; Cherry, A.; Kamenetsky, M.; Cherry, A. Composition and emplacement of the Benfontein kimberlite sill complex (Kimberley, South Africa): Textural, petrographic and melt inclusion constraints. Lithos 2019, 324-325, 297-314. [CrossRef]

49. Dawson, J.B.; Hawthorne, J.B. Magmatic sedimentation and carbonatitic differentiation in kimberlite sills at Benfontein, South Africa. J. Geol. Soc. London 1973, 12, 61-85. [CrossRef]

50. Pascal, M.-L.; Fonteilles, M.; Boudouma, O.; Principe, C. Qandilite from Vesuvius skarn ejecta: Conditions of formation and miscibility gap in the ternary spinel-qandilite-magnesioferrite. Can. Mineral. 2011, 49, 459-485. [CrossRef]

51. Fuchs, L.H. Djerfisherite, alkali copper-iron sulfide: A new mineral from enstatite chondrites. Science 1966, 153, 166-167. [CrossRef]

52. Kogarko, L.N.; Plant, D.A.; Henderson, C.M.B.; Kjarsgaard, B.A. Na-rich carbonate inclusions in perovskite and calzirtite from the Guli intrusive Ca-carbonatite, polar Siberia. Contrib. Mineral. Petrol. 1991, 109, 124-129. [CrossRef]

53. Korobeinikov, A.N.; Mitrofanov, F.P.; Gehor, S.; Laajoki, K.; Pavlov, V.P.; Mamontov, V.P. Geology and copper sulphide mineralization of the Salmagorskii Ring igneous complex, Kola Peninsula, NW Russia. J. Petrol. 1998, 39, 2033-2041. [CrossRef]

54. Clarke, D.B.; Chapman, C.A.T.; MacKay, R.M.; Mitchell, R.H. Occurrence and origin of djerfisherite from the Elwin Bay Kimberlite, Somerset Island, Northwest Territories. Can. Mineral. 1994, 32, 815-823.

55. Sharygin, V.V.; Kamenetsky, V.S.; Kamenetsky, M.B. Potassium sulfides in kimberlite-hosted chloride-"nyerereite" and chloride clasts of Udachnaya-East Pipe, Yakutia, Russia. Can. Mineral. 2008, 46, 1079-1095. [CrossRef]

56. Dawson, J.B.; Smith, J.V.; Steele, I.M. Petrology and Mineral Chemistry of Plutonic Igneous Xenoliths from the Carbonatite Volcano, Oldoinyo Lengai, Tanzania. J. Petrol. 1995, 36, 797-826. [CrossRef]

57. Solovova, I.P.; Girnis, A.V.; Ryabchikov, I.D. Inclusions of carbonate and silicate melts in minerals of alkali basaltoids from the East Pamirs. Petrology 1996, 4, 319-341.

58. Panina, L.I.; Sazonov, A.M.; Usol'tseva, L.M. Melilitic and monticellite- bearing rocks of the Krestovskaya intrusion (northern Siberian Platform) and their genesis. Geol. Geofiz. 2001, 42, 1314-1332.

59. Spetsius, Z.V.; Bulanova, G.P.; Leskova, N.V. Djerfisherite and its genesis in kimberlitic rocks. Dokl. Akad. Nauk. 1987, 293, 199-202.

60. Bulanova, G.P.; Shestakova, O.E.; Leskova, N.V. Djerfisherite in diamond-hosted sulfide inclusions. Dokl. Akad. Nauk. 1980, 225, 430-433.

61. Golovin, A.V.; Sharygin, V.V.; Pokhilenko, N.P.; Mal'kovets, V.G.; Kolesov, B.A.; Sobolev, N.V. Secondary melt inclusions in olivine from unaltered kimberlites of the Udachnaya-East pipe, Yakuti. Dokl. Earth Sci. 2003, 388, 93-96.

62. Kamenetsky, V.S.; Maas, R.; Kamenetsky, M.B.; Paton, C.; Phillips, D.; Golovin, A.V.; Gornova, M.A. Chlorine from the mantle: Magmatic halides in the Udachnaya-East kimberlite, Siberia. Earth Planet. Sci. Lett. 2009, 285, 96-104. [CrossRef] 
63. Logvinova, A.M.; Wirth, R.; Fedorova, E.N.; Sobolev, N.V. Nanometre-sized mineral and fluid inclusions in cloudy Siberian diamonds: New insights on diamond formation. Eur. J. Mineral. 2008, 20, 317-331. [CrossRef]

64. Minin, D.A.; Sharygin, I.S.; Litasov, K.D.; Sharygin, V.V.; Shatskiy, A.; Ohtani, E. High-pressure stability of djerfisherite: Implication for its origin in diamonds and mantle xenoliths. Proceedings of Advances in high Pressure Research II: Deepest Understanding 2015, Novosibirsk-Irkutsk, Russia, 29 August-4 September 2015; p. 14.

65. Sharygin, I.S.; Golovin, A.V.; Pokhilenko, N.P. Djerfisherite in xenoliths of sheared peridotite in the Udachnaya-East pipe (Yakutia): Origin and relationship with kimberlitic magmatism. Russ. Geol. Geophys. 2012, 53, 247-261. [CrossRef]

66. Abersteiner, A.; Kamenetsky, V.S.; Goemann, K.; Golovin, A.V.; Sharygin, I.S.; Giuliani, A.; Rodemann, T.; Spetsius, Z.V.; Kamenetsky, M. Djerfisherite in kimberlites and their xenoliths: Implications for kimberlite melt evolution. Contrib. Mineral. Petrol. 2019, 174, 8. [CrossRef]

67. Chakhmouradian, A.R.; Mitchell, R.H. Three compositional varieties of perovskite from kimberlites of the Lac de Gras field (Northwest Territories, Canada). Mineral. Mag. 2001, 65, 133-148. [CrossRef]

68. Kitayama, Y.; Thomassot, E.; Galy, A.; Golovin, A.; Korsakov, A.; D’Eyrames, E.; Assayag, N.; Bouden, N.; Ionov, D. Co-magmatic sulfides and sulfates in the Udachnaya-East pipe (Siberia): A record of the redox state and isotopic composition of sulfur in kimberlites and their mantle sources. Chem. Geol. 2017, 455, 315-330. [CrossRef]

(C) 2020 by the authors. Licensee MDPI, Basel, Switzerland. This article is an open access article distributed under the terms and conditions of the Creative Commons Attribution (CC BY) license (http://creativecommons.org/licenses/by/4.0/). 